\title{
Characterization of Odorous Compounds (VOC and Carbonyl Compounds) in the Ambient Air of Yeosu and Gwangyang, Large Industrial Areas of South Korea
}

\author{
Young-Kyo Seo, Lakshmi Narayana Suvarapu, and Sung-Ok Baek \\ Department of Environmental Engineering, Yeungnam University, Gyeongsan-si 712 749, Republic of Korea \\ Correspondence should be addressed to Sung-Ok Baek; sobaek@yu.ac.kr
}

Received 18 July 2014; Accepted 20 August 2014; Published 17 September 2014

Academic Editor: Ki-Hyun Kim

Copyright (C) 2014 Young-Kyo Seo et al. This is an open access article distributed under the Creative Commons Attribution License, which permits unrestricted use, distribution, and reproduction in any medium, provided the original work is properly cited.

\begin{abstract}
Odorous compounds play an important role in air pollution in industrial areas and the residential areas surrounding them. This study measured the odorous volatile organic compounds (VOC) and carbonyl compounds at Yeosu and Gwangyang, two large industrial areas of South Korea, during four seasons of 2008-2009. Along with these two cities, the same odorous compounds were measured at Suncheon, which was selected as a control site. The concentrations of VOC and carbonyl compounds that were listed as odorous air pollutants by the Ministry of Environment of South Korea are discussed. Benzene and formaldehyde were included in the target analytes because of their carcinogenic nature. Most researchers only examined the concentration of odorous compounds in ambient air but the present study evaluated the odor intensity, which is a new parameter that will help better understand the precise odor perceived by people. This paper describes the seasonal variations and spatial distribution of the above-mentioned odorous compounds at the specified sites. Pearson correlation coefficients between the odorous compounds and other air pollutants, such as ozone, $\mathrm{CO}, \mathrm{SO}_{2}, \mathrm{NO}_{2}$, and $\mathrm{PM}_{10}$, and meteorological conditions, such as temperature and wind speed, provide the source information of odorous VOC and carbonyl compounds.
\end{abstract}

\section{Introduction}

The monitoring of odorous compounds in ambient air is an important task to environmental researchers because of the presence of some toxic volatile organic compounds (VOC) and carbonyl compounds in odorous compounds. The VOC and carbonyl compounds present in malodors have adverse effects on the air quality in the surrounding areas of the sources [1] as well as on health of the people residing near the sources. The major sources for odorous compounds include agricultural waste, food processing industries [2,3], composting of municipal solid wastes [4], livestock production industries [5], semiconductor industries [6], and the incomplete combustion of hydrocarbon fuels in a range of industries [7]. The use of ethanol in industries also results in the release of odorous carbonyl compounds into the atmosphere [8]. Therefore, many countries are struggling to develop effective odor regulations or guidelines to decrease their concentrations in ambient air [2]. In recent years, many researchers have reported the concentrations of odorous compounds in the atmosphere in Korea and around the world with respect to their hazardous and/or toxic nature to humans [7-12]. In South Korea, the Ministry of Environment identifies 22 compounds as malodourous in the atmosphere [13]. Among these 22 malodorous compounds, $50 \%$ belong to VOC (toluene, styrene, m,p,o-xylenes, methyl isobutyl ketone, and ethyl acetate) and carbonyl compounds (acetaldehyde, propanal, n-butanal, n-valeraldehyde, $i$-valeraldehyde, and methyl ethyl ketone).

In addition to odor, the carbonyl compounds have also attracted the attention of researchers to measure their concentrations in ambient air because of their ozone formation potential by means of photochemical reactions and their adverse health effects on humans $[14,15]$.

In the present study, ambient air samples were collected to measure the concentrations of odorous compounds including VOC and carbonyl compounds in two large industrial cities of South Korea, namely, Yeosu and Gwangyang. To compare 


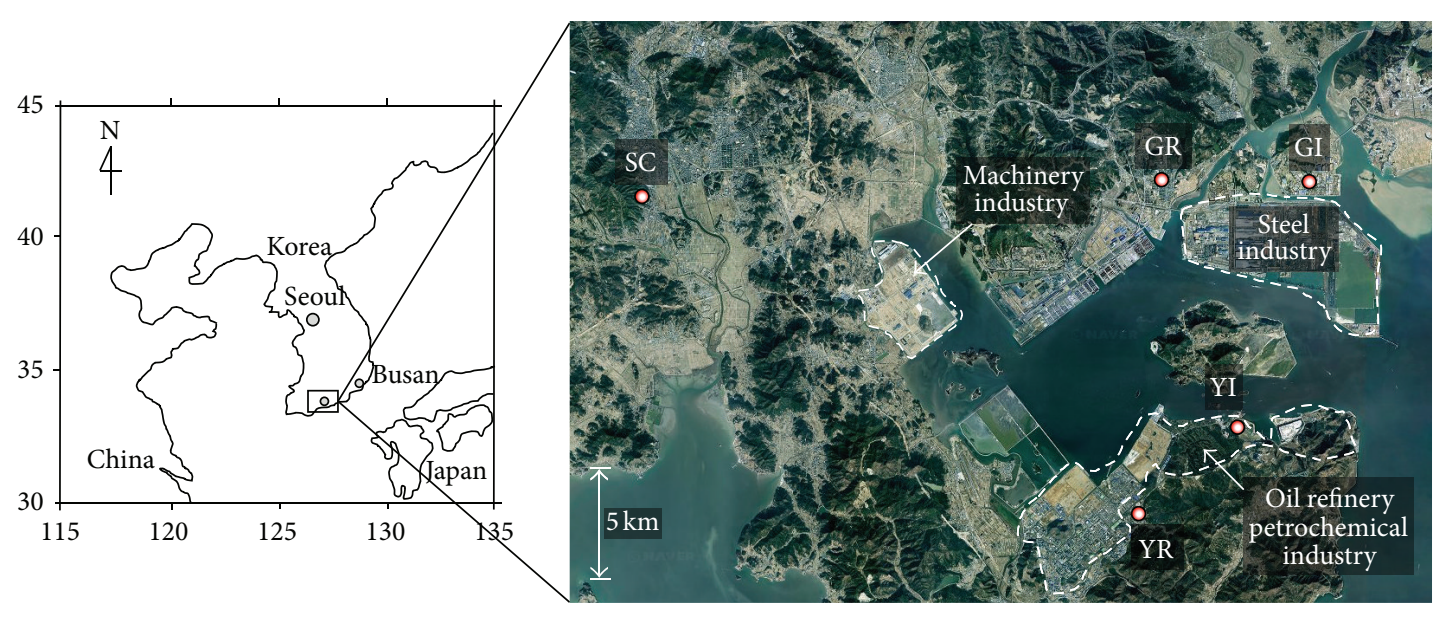

Figure 1: Location of the sampling sites at Yeosu, Gwangyang, and Suncheon.

the concentrations of the selected compounds at these cities, Suncheon, which is a purely residential site and almost $25 \mathrm{~km}$ away from industrial complexes, was chosen as the control site (Figure 1).

Yeosu $\left(34^{\circ} 44^{\prime} \mathrm{N} 127^{\circ} 44^{\prime} \mathrm{E}\right)$, which is situated in Jeolla province, South Korea, is an important industrial city. The population is approximately 300,000 according to the 2009 census and has an area of $503.33 \mathrm{~km}^{2}$. This city has more tourist attractions as an ocean resort and is also close to the Yeocheon Industrial Complex. This importance made this city a host to the 2012 World Expo (http://en.wikipedia.org/ wiki/Yeosu). The major industries located in this city are related to oil refineries and petrochemicals. In Yeosu, ambient air samples were collected at two sites: pure industrial site and a residential site near the industrial complexes. These two sites were $5 \mathrm{~km}$ from each other (Figure 1). Gwangyang $\left(34^{\circ} 56^{\prime} \mathrm{N} 127^{\circ} 41^{\prime} \mathrm{E}\right)$ is also important and large industrial cities of South Korea located in South Jeolla province of the country. This is the home of the POSCO (Pohang Steel Company), which is one of the world's largest steel companies. This city has a population and area of approximately 150,000 and $309.4 \mathrm{Km}$, respectively (http://en.wikipedia.org/wiki/ Gwangyang, accessed on July 10, 2014). The major industries located in this city are related to steel companies. In the present study, ambient air samples were collected at two sites of Gwangyang representing industrial and residential areas separated by a distance of $5 \mathrm{~km}$ (Figure 1).

This paper reports the measured odorous VOC and carbonyl compounds at Yeosu and Gwangyang, which are two important industrial cities of South Korea during the four seasons of 2008-2009. The concentrations of benzene and formaldehyde were also measured, even though they are not listed as odorous compounds in South Korea because of their carcinogenic nature $[16,17]$. The concentrations of odorous VOC and carbonyl compounds measured at these industrial cities were also compared with those measured at Suncheon, a nonindustrial control site. The odor intensity of each VOC and carbonyl compounds was also evaluated to determine the precise odor impact of these compounds on humans. This is the first comprehensive study in Korea regarding the monitoring of VOC and carbonyl compounds in ambient air in terms of the huge number of samples and variety of odorous compounds.

\section{Materials and Methods}

2.1. Sampling Sites and Sampling Periods. Ambient air samples were collected for an analysis of VOC and carbonyl compounds at Yeosu Industrial (YI), Yeosu Residential (YR), Gwangyang Industrial (GI), Gwangyang Residential (GR), and Suncheon Control (SC) sties, for 10 consecutive days during spring (May 20-29), summer (August 5-14), and fall (October 17-26) of 2008 and winter (January 13-22) of 2009. At all sampling sites and for all seasons, two samples were collected manually for an analysis of carbonyl compounds for a $2 \mathrm{~h}$ duration and six samples were collected using an automatic continuous sampler for VOC analysis at a $4 \mathrm{~h}$ duration on each sampling day. On the other hand, at the YR site, only two VOC samples were collected manually per day in summer and spring and two samples per day in summer at the GR site. This is largely due to the instrumental availability during the specified period. According to the Korean Meteorological Administration (http://web.kma.go.kr/eng/index.jsp, accessed on July $10,2014)$, the average temperatures observed in spring, summer, fall, and winter at Yeosu were $20.9^{\circ} \mathrm{C}, 28.2^{\circ} \mathrm{C}, 19.4^{\circ} \mathrm{C}$, and $3.1^{\circ} \mathrm{C}$, respectively. The mean temperatures observed in spring, summer, fall, and winter at Gwangyang were $20.5^{\circ} \mathrm{C}$, $27.5^{\circ} \mathrm{C}, 17.2^{\circ} \mathrm{C}$, and $2.9^{\circ} \mathrm{C}$, respectively.

\subsection{Sampling and Analysis of VOC and Carbonyl Compounds.} Stainless steel tubes $\left(1 / 4^{\prime \prime} \times 9 \mathrm{~cm}\right.$, Perkin Elmer, UK), packed with $120 \mathrm{mg}$ Carbograph 2TD and $280 \mathrm{mg}$ of Carbograph 1TD (40/60 mesh, Markes, UK), a low flow rate pump equipped with a mass flow controller (Flec, Chematec Inc., Denmark), and a sequential automatic tube sampler (STS 25, Perkin Elmer, UK) were used to determine the concentration of odorous VOC at the specified sites. The sampling of VOC was carried out at a flow rate of $100 \mathrm{~mL} / \mathrm{min}$ for $4 \mathrm{~h}$ per each tube. Preconditioning of the adsorbent tubes was performed before 
TABLE 1: Analytical conditions for VOC with thermodesorption GC/MSD.

\begin{tabular}{lccc}
\hline & Thermal desorber & & GC/MSD \\
& UNITY/ULTRA (Markes, UK) & GC column & Rtx-1 $(0.32 \mathrm{~mm}, 105 \mathrm{~m}, 1.5 \mu \mathrm{m})$ \\
Oven temp. & $300^{\circ} \mathrm{C}$ & Initial temp. & $50^{\circ} \mathrm{C}(10 \mathrm{~min})$ \\
Desorb time & $10 \mathrm{~min}$ & Oven ramp rate & $5{ }^{\circ} \mathrm{C} / \mathrm{min}$ \\
Desorb flow & $50 \mathrm{~mL} / \mathrm{min}$ & Final temp. & $250^{\circ} \mathrm{C}(5 \mathrm{~min})$ \\
Cold trap holding time & $5 \mathrm{~min}$ & Post run & $250^{\circ} \mathrm{C}(5 \mathrm{~min})$ \\
Cold trap high temp. & $320^{\circ} \mathrm{C}$ & Column flow & $1.13 \mathrm{~mL} / \mathrm{min}$ \\
Cold trap low temp. & $-10^{\circ} \mathrm{C}$ & Detector type & Quadropole \\
Cold trap packing & Tenax TA/carbopack B & Q-pole temp. & $150^{\circ} \mathrm{C}$ \\
Min. pressure & $12 \mathrm{psi}$ & MS Source temp. & $230^{\circ} \mathrm{C}$ \\
Inlet split & $\mathrm{No}$ & Mass range & $35 \sim 300 \mathrm{amu}$ \\
Outlet split & $10 \mathrm{~mL} / \mathrm{min}$ & Electron energy & $70 \mathrm{eV}$ \\
Valve and line temp. & $180^{\circ} \mathrm{C}$ & & \\
\hline
\end{tabular}

TABle 2: Physicochemical characteristics of odor compounds in this study.

\begin{tabular}{|c|c|c|c|c|c|c|}
\hline \multirow{2}{*}{ Compounds } & \multirow{2}{*}{ Abb. } & \multirow{2}{*}{ CAS No. } & \multicolumn{2}{|c|}{ Odorous compounds } & \multirow{2}{*}{$\mathrm{MW}(\mathrm{g} / \mathrm{mol})$} & \multirow{2}{*}{$\mathrm{Bp}\left({ }^{\circ} \mathrm{C}\right)$} \\
\hline & & & Korea & Japan & & \\
\hline Benzene & $\mathrm{BZ}$ & $71-43-2$ & - & - & 78.11 & 80.1 \\
\hline Ethyl acetate & EA & $141-78-6$ & - & O & 88.11 & 77.1 \\
\hline Methyl isobutyl ketone & MIBK & $108-10-1$ & O & O & 100.16 & 117.0 \\
\hline Toluene & TOL & $108-88-3$ & ○ & ○ & 92.14 & 111.0 \\
\hline$m, p$-Xylenes & $\operatorname{mpXYLN}$ & $\begin{array}{l}108-38-3 \\
106-42-3\end{array}$ & O & O & 106.16 & 139.0 \\
\hline$o$-Xylene & oXYLN & $95-47-6$ & O & O & 106.17 & 144.4 \\
\hline Styrene & STR & $100-42-5$ & O & O & 104.15 & 145.0 \\
\hline Formaldehyde & FRML & $50-00-0$ & - & - & 30.03 & -19.0 \\
\hline Acetaldehyde & ACTL & $75-07-0$ & O & O & 44.05 & 20.2 \\
\hline Propionaldehyde & PPNL & $123-38-6$ & O & O & 58.08 & 46.0 \\
\hline Methyl ethyl ketone & MEK & $78-93-3$ & O & - & 72.11 & 79.6 \\
\hline Butyraldehyde & BTL & $123-72-8$ & O & O & 72.11 & 74.8 \\
\hline$i$-Valeraldehyde & iVAL & $590-86-3$ & ○ & O & 86.13 & 92.0 \\
\hline$n$-Valeraldehyde & nVAL & $100-62-3$ & O & O & 86.13 & 102.0 \\
\hline
\end{tabular}

sampling at the temperature of $250^{\circ} \mathrm{C}$ for $2 \mathrm{~h}$ with helium as the carrier gas. The performance of the adsorbent tubes used in this study was tested previously by the author's research group [37, 38]. Table 1 lists the analytical and operating conditions for this system. The total analytical procedure followed in the analysis of VOC was described in detail in a previous research paper [39]. Table 2 lists the physicalchemical characteristics of both odorous VOC and carbonyl compounds.

For the qualitative and quantitative determination and analysis of carbonyl compounds, the calibration of carbonylDNPH mixture (Supelco Inc., USA) was performed with the standard working solutions diluted as $0.25,0.5,1.0,3.0$, and $15.0 \mu \mathrm{g} / \mathrm{mL}$ in the case of formaldehyde. The commercial standard mixture did not contain the methyl ethyl ketone, which was calibrated separately using an individual standard after dilution.
The sampling of carbonyl compounds was performed using DNPH cartridges (C18 Sep-Pak short-body cartridges coated with DNPH, Supelco Inc., USA). The interference of ozone during sampling was removed by connecting a polypropylene tube filled with KI $(\sim 1.4 \mathrm{~g})$ at the front side of the DNPH cartridge. During sampling, a total volume of $120 \mathrm{~L}$ of ambient air was collected at a flow rate of $1 \mathrm{~L} / \mathrm{min}$ using a sampling pump. The resulting samples were kept in a refrigerator prior to the analysis of carbonyl compounds through the solvent extraction process. The DNPH derivatives were then extracted with $4 \mathrm{~mL}$ of acetonitrile and the extracted solution was transferred into an amber vial (to avoid contact with sunlight), sealed tightly with Teflon tape and stored in refrigerator. All glassware used during the solvent extraction process was prewashed with acetonitrile and dried over $60^{\circ} \mathrm{C}$ prior to use. The extracted DNPH derivatives were analyzed by HPLC with a UV detector at $360 \mathrm{~nm}$ [40]. Table 3 lists 

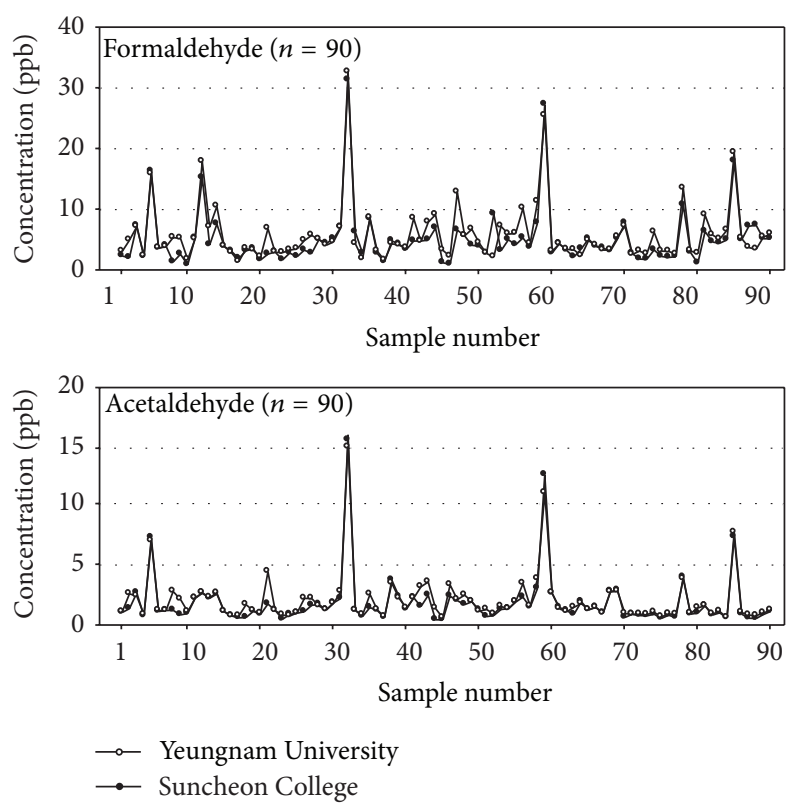

FIGURE 2: Concentrations of formaldehyde and acetaldehyde obtained during the analysis at Yeungnam University and Suncheon College (interlab comparison).

TABLE 3: Operating conditions for the HPLC analysis of carbonyl compounds.

\begin{tabular}{ll}
\hline $\begin{array}{l}\text { Operating } \\
\text { parameter }\end{array}$ & Specifications and conditions \\
\hline HPLC system & $\begin{array}{l}\text { Shimadzu SCL-6B with Shimadzu SPD-6 } \\
\text { AV UV/VIS detector at } 360 \mathrm{~nm} \\
\text { Shim-Pack CL-ODS }(\mathrm{M}) 4.6 \mathrm{~mm} \times\end{array}$ \\
Analytical column & $\begin{array}{l}150 \mathrm{~mm} \text { with a } \mathrm{C}_{18} \text { guard column } \\
\text { A: acetonitrile } 100(\mathrm{~V}),\end{array}$ \\
Mobile phase & $\begin{array}{l}\mathrm{B}: \text { water/acetonitrile/tetrahydrofuran } \\
50 / 45 / 5(\mathrm{v} / \mathrm{v})\end{array}$ \\
& $\begin{array}{l}100 \% \text { for B for } 5 \text { min, and then } 60: 40 \% \\
\text { Gradient elution }\end{array}$ \\
$\begin{array}{l}\text { Flow rate and } \\
\text { injection volume }\end{array}$ & $1.0 \mathrm{~mL} / \mathrm{min}$ and $20 \mu \mathrm{L}$ injection
\end{tabular}

all the operating conditions used in HPLC analysis of the carbonyl compounds.

2.3. Quality Control and Quality Assurance. Detailed calibration process of VOC followed in this study was prescribed in a previous research paper [39]. The precision of the present method for an analysis of VOC was evaluated by the relative standard deviation (RSD) of the retention time and peak area of a known amount of VOC standard injected into each adsorbent tube. Overall, the RSDs for the peak area appeared to be $<8 \%$, whereas those for the retention time were $<0.5 \%$. The detection limit for the present method was evaluated according to the US EPA TO-17 method protocol [41] and was obtained as $0.01-0.06 \mathrm{ppb}$, depending on the individual VOC.
The repeatability of the present method was evaluated using the relative standard deviation (RSD) of the peak areas for a standard mixture $(0.25 \mu \mathrm{g} / \mathrm{mL})$. The RSD of the present method within a day appeared to be less than 3.5\% and between days it was less than $8.0 \%$. The detection limit for the analysis of carbonyl compounds in the present method was evaluated using the guidelines of the US EPA [42] and was obtained as $1.1 \sim 2.3 \mathrm{ng} / \mathrm{mL}$, which is equal to $0.01 \sim$ $0.02 \mathrm{ppb}$ (as the concentration in the air based on the total volume of $120 \mathrm{~L}$ ). The accuracy of the present analytical method was tested by an interlaboratory comparison of the analytical data of the concentrations of carbonyl compounds. For an interlaboratory comparison, 90 carbonyl samples were taken in random and analyzed in the author's laboratory (Yeungnam University, Korea) and another laboratory (Suncheon College, Korea). Figure 2 shows the concentrations of both formaldehyde and acetaldehyde during interlaboratory analysis which is a similar trend for all samples in two laboratories. Table 4 lists the statistical parameters of the interlaboratory comparison, which indicates an excellent correlation between the data obtained in the two laboratories.

\section{Results and Discussion}

3.1. Occurrence and Distribution of VOC and Carbonyl Compounds. Table 5 lists the detection frequencies and the mean, median, minimum, and maximum concentrations of the odorous VOC measured at Yeosu Industrial (YI), Yeosu Residential (YR), Gwangyang Industrial (GI), Gwangyang Residential (GR), and Suncheon Control (SC) sites. Benzene, toluene, and $m, p, o$-xylenes were found with detection frequencies in the range from 95 to $100 \%$ at all sites. With 
TABLE 4: Interlaboratory comparison of the concentration of same carbonyl compounds analyzed at author's laboratory (Yeungnam University, YNU) and another laboratory (Suncheon College, SCC).

\begin{tabular}{|c|c|c|c|c|c|c|c|}
\hline Compounds & Sample number & $\operatorname{MDP}^{(1)}(\%)$ & $\operatorname{MRE~I}^{(2)}(\%)$ & MRE II $^{(3)}(\%)$ & $R^{(4)}$ & $t$-test $(P$ value $)$ & Paired $t$-test $(P$ value $)$ \\
\hline Formaldehyde & 90 & 27.8 & 23.9 & 37.8 & $0.94^{*(5)}$ & 0.2 & 0 \\
\hline Acetaldehyde & 90 & 18.5 & 15.3 & 25.6 & $0.97^{*}$ & 0.46 & 0 \\
\hline \multicolumn{8}{|c|}{${ }^{(1)} \mathrm{MDP}($ mean duplicate precision, $\%)=(1 / n) \sum_{n=1}^{n}(|\mathrm{YNU}-\mathrm{SCC}| / \mathrm{Mean}) \times 100(\%)$} \\
\hline \multicolumn{8}{|c|}{ (2) MRE I (mean relative error, \%) $=(1 / n) \sum_{n=1}^{n}(\mid \mathrm{YNU}-\mathrm{SCC} / / \mathrm{YNU}) \times 100(\%)$} \\
\hline \multicolumn{8}{|c|}{${ }^{(3)}$ MRE II (mean relative error, $\left.\%\right)=(1 / n) \sum_{n=1}^{n}(|\mathrm{YNU}-\mathrm{SCC}| / \mathrm{SCC}) \times 100(\%)$. } \\
\hline${ }^{(4)} R$ : correlation c & efficient. & & & & & & \\
\hline
\end{tabular}

TABLE 5: Statistical summaries of the VOC at different sites in the present study.

\begin{tabular}{|c|c|c|c|c|c|c|c|}
\hline Sites & VOC & Detection frequency & Mean (ppb) & S.D. (ppb) & Median (ppb) & Min (ppb) & $\operatorname{Max}(\mathrm{ppb})$ \\
\hline \multirow{7}{*}{$\begin{array}{l}\text { YI } \\
(n=234)\end{array}$} & Ethyl acetate & $79 \%$ & 0.39 & 1.29 & 0.11 & N.D. & 16.75 \\
\hline & Benzene & $100 \%$ & 3.65 & 6.86 & 1.75 & 0.14 & 38.31 \\
\hline & Methyl isobutyl ketone & $26 \%$ & 0.11 & 0.23 & N.D. & N.D. & 1.46 \\
\hline & Toluene & $100 \%$ & 3.25 & 4.40 & 2.01 & 0.06 & 38.61 \\
\hline & $m, p$-Xylenes & $100 \%$ & 2.50 & 3.57 & 1.17 & 0.06 & 25.61 \\
\hline & Styrene & $48 \%$ & 0.25 & 0.44 & N.D. & N.D. & 4.07 \\
\hline & $o$-Xylene & $100 \%$ & 0.58 & 0.65 & 0.34 & 0.02 & 4.47 \\
\hline \multirow{7}{*}{$\begin{array}{l}\text { YR } \\
(n=160)\end{array}$} & Ethyl acetate & $76 \%$ & 0.11 & 0.12 & 0.07 & N.D. & 0.49 \\
\hline & Benzene & $100 \%$ & 1.07 & 1.02 & 0.75 & 0.04 & 5.93 \\
\hline & Methyl isobutyl ketone & $9 \%$ & 0.01 & 0.04 & N.D. & N.D. & 0.23 \\
\hline & Toluene & $100 \%$ & 1.61 & 2.09 & 0.98 & 0.05 & 17.41 \\
\hline & $m, p$-Xylenes & $99 \%$ & 0.36 & 0.35 & 0.20 & N.D. & 1.71 \\
\hline & Styrene & $29 \%$ & 0.15 & 0.34 & N.D. & N.D. & 1.82 \\
\hline & $o$-Xylene & $98 \%$ & 0.10 & 0.09 & 0.07 & N.D. & 0.47 \\
\hline \multirow{7}{*}{$\begin{array}{l}\text { GI } \\
(n=239)\end{array}$} & Ethyl acetate & $62 \%$ & 0.12 & 0.22 & 0.05 & N.D. & 1.64 \\
\hline & Benzene & $100 \%$ & 1.64 & 3.83 & 0.40 & 0.06 & 27.12 \\
\hline & Methyl isobutyl ketone & $6 \%$ & 0.01 & 0.05 & N.D. & N.D. & 0.37 \\
\hline & Toluene & $100 \%$ & 0.97 & 0.87 & 0.75 & 0.04 & 8.45 \\
\hline & $m, p$-Xylenes & $99 \%$ & 1.09 & 5.78 & 0.28 & N.D. & 27.36 \\
\hline & Styrene & $4 \%$ & 0.01 & 0.05 & N.D. & N.D. & 0.46 \\
\hline & $o$-Xylene & $97 \%$ & 0.28 & 1.22 & 0.08 & N.D. & 16.06 \\
\hline \multirow{7}{*}{$\begin{array}{l}\text { GR } \\
(n=199)\end{array}$} & Ethyl acetate & $73 \%$ & 0.10 & 0.13 & 0.06 & N.D. & 0.83 \\
\hline & Benzene & $100 \%$ & 0.59 & 0.72 & 0.40 & 0.07 & 6.66 \\
\hline & Methyl isobutyl ketone & $3 \%$ & $<0.01$ & 0.03 & N.D. & N.D. & 0.29 \\
\hline & Toluene & $100 \%$ & 0.98 & 0.77 & 0.78 & 0.01 & 4.10 \\
\hline & $m, p$-Xylenes & $98 \%$ & 0.37 & 0.36 & 0.23 & N.D. & 2.43 \\
\hline & Styrene & $2 \%$ & $<0.01$ & 0.02 & N.D. & N.D. & 0.27 \\
\hline & $o$-Xylene & $95 \%$ & 0.11 & 0.10 & 0.08 & N.D. & 0.52 \\
\hline \multirow{7}{*}{$\begin{array}{l}\text { SC } \\
(n=240)\end{array}$} & Ethyl acetate & $53 \%$ & 0.07 & 0.11 & 0.03 & N.D. & 1.11 \\
\hline & Benzene & $100 \%$ & 0.38 & 0.25 & 0.33 & 0.04 & 2.11 \\
\hline & Methyl isobutyl ketone & $1 \%$ & $<0.01$ & 0.01 & N.D. & N.D. & 0.12 \\
\hline & Toluene & $100 \%$ & 0.68 & 0.60 & 0.52 & 0.01 & 5.02 \\
\hline & $m, p$-Xylenes & $97 \%$ & 0.20 & 0.19 & 0.17 & N.D. & 1.34 \\
\hline & Styrene & $0 \%$ & $<0.01$ & 0.01 & N.D. & N.D. & 0.12 \\
\hline & $o$-Xylene & $87 \%$ & 0.06 & 0.06 & 0.05 & N.D. & 0.36 \\
\hline
\end{tabular}

N.D.: not detected. 
TABLE 6: Statistical summaries of carbonyl compounds at different sites of the present study.

\begin{tabular}{|c|c|c|c|c|c|c|c|}
\hline Sites & Carbonyl compounds & Detection frequency & Mean (ppb) & S.D. (ppb) & Median (ppb) & $\operatorname{Min}(\mathrm{ppb})$ & $\operatorname{Max}(\mathrm{ppb})$ \\
\hline \multirow{7}{*}{$\begin{array}{l}\mathrm{YI} \\
(n=80)\end{array}$} & Formaldehyde & $96 \%$ & 7.40 & 5.74 & 4.81 & N.D. & 26.93 \\
\hline & Acetaldehyde & $96 \%$ & 2.75 & 2.02 & 2.24 & N.D. & 9.89 \\
\hline & Propionaldehyde & $60 \%$ & 0.29 & 0.40 & 0.18 & N.D. & 2.67 \\
\hline & Methyl ethyl ketone & $74 \%$ & 2.57 & 3.73 & 1.06 & N.D. & 15.92 \\
\hline & Butyraldehyde & $5 \%$ & 0.06 & 0.34 & N.D. & N.D. & 2.67 \\
\hline & $i$-Valeraldehyde & $11 \%$ & 0.03 & 0.09 & N.D. & N.D. & 0.50 \\
\hline & $n$-Valeraldehyde & $31 \%$ & 0.11 & 0.22 & N.D. & N.D. & 0.95 \\
\hline \multirow{7}{*}{$\begin{array}{l}\mathrm{YR} \\
(n=78)\end{array}$} & Formaldehyde & $99 \%$ & 8.06 & 6.27 & 5.88 & N.D. & 31.38 \\
\hline & Acetaldehyde & $97 \%$ & 3.43 & 3.05 & 2.10 & N.D. & 15.74 \\
\hline & Propionaldehyde & $50 \%$ & 0.35 & 0.61 & 0.06 & N.D. & 2.97 \\
\hline & Methyl ethyl ketone & $73 \%$ & 2.05 & 2.93 & 0.96 & N.D. & 13.73 \\
\hline & Butyraldehyde & $29 \%$ & 0.56 & 1.25 & N.D. & N.D. & 6.08 \\
\hline & $i$-Valeraldehyde & $12 \%$ & 0.03 & 0.10 & N.D. & N.D. & 0.46 \\
\hline & $n$-Valeraldehyde & $26 \%$ & 0.05 & 0.11 & N.D. & N.D. & 0.48 \\
\hline \multirow{7}{*}{$\begin{array}{l}\mathrm{GI} \\
(n=79)\end{array}$} & Formaldehyde & $99 \%$ & 5.99 & 4.55 & 4.89 & N.D. & 30.52 \\
\hline & Acetaldehyde & $99 \%$ & 1.97 & 1.12 & 1.85 & N.D. & 5.35 \\
\hline & Propionaldehyde & $44 \%$ & 0.14 & 0.18 & N.D. & N.D. & 0.64 \\
\hline & Methyl ethyl ketone & $91 \%$ & 2.74 & 3.12 & 2.04 & N.D. & 20.56 \\
\hline & Butyraldehyde & $4 \%$ & 0.02 & 0.08 & N.D. & N.D. & 0.51 \\
\hline & $i$-Valeraldehyde & $8 \%$ & 0.02 & 0.06 & N.D. & N.D. & 0.39 \\
\hline & $n$-Valeraldehyde & $28 \%$ & 0.07 & 0.13 & N.D. & N.D. & 0.54 \\
\hline \multirow{7}{*}{$\begin{array}{l}\text { GR } \\
(n=80)\end{array}$} & Formaldehyde & $100 \%$ & 7.15 & 5.54 & 5.45 & 1.65 & 28.66 \\
\hline & Acetaldehyde & $100 \%$ & 2.23 & 1.68 & 1.86 & 0.13 & 12.44 \\
\hline & Propionaldehyde & $34 \%$ & 0.17 & 0.47 & N.D. & N.D. & 3.92 \\
\hline & Methyl ethyl ketone & $86 \%$ & 2.29 & 3.02 & 1.86 & N.D. & 22.34 \\
\hline & Butyraldehyde & $1 \%$ & 0.01 & 0.05 & N.D. & N.D. & 0.44 \\
\hline & $i$-Valeraldehyde & $4 \%$ & 0.01 & 0.06 & N.D. & N.D. & 0.40 \\
\hline & $n$-Valeraldehyde & $11 \%$ & 0.03 & 0.08 & N.D. & N.D. & 0.37 \\
\hline \multirow{7}{*}{$\begin{array}{l}\text { SC } \\
(n=80)\end{array}$} & Formaldehyde & $98 \%$ & 6.52 & 4.84 & 5.30 & N.D. & 25.81 \\
\hline & Acetaldehyde & $98 \%$ & 2.54 & 2.87 & 1.48 & N.D. & 18.38 \\
\hline & Propionaldehyde & $38 \%$ & 0.21 & 0.43 & N.D. & N.D. & 2.91 \\
\hline & Methyl ethyl ketone & $78 \%$ & 2.05 & 2.11 & 1.75 & N.D. & 8.59 \\
\hline & Butyraldehyde & $10 \%$ & 0.10 & 0.43 & N.D. & N.D. & 2.77 \\
\hline & $i$-Valeraldehyde & $5 \%$ & 0.03 & 0.15 & N.D. & N.D. & 0.84 \\
\hline & $n$-Valeraldehyde & $18 \%$ & 0.05 & 0.12 & N.D. & N.D. & 0.58 \\
\hline
\end{tabular}

N.D.: not detected.

the exception of the YI site, styrene and methyl isobutyl ketone were found at detection frequencies below 30\% and $9 \%$, respectively, at all other sites. Overall, at Yeosu industrial site, all the VOC were observed at higher detection frequencies than the other sites. From Table 5, it is clear that the most abundant odorous VOC found at all these sites was toluene followed by $m, p, o$-xylenes. In addition to odorous VOC, benzene, the most important and carcinogenic VOC, was found at higher levels at all these sites than in any other VOC measured. The national air quality standard for benzene, as an annual average concentration, was established as $1.5 \mathrm{ppb}$, in Korea. The concentration of benzene was found to be higher than the Korean standard level at the industrial sites (YI and GI) and lower at the residential areas (YR and GR) and control site (SC). Regarding the odorous VOC, the least abundant compounds were methyl isobutyl ketone and styrene.

Table 6 lists the detection frequencies and the mean, median, minimum, and maximum level concentrations of odorous carbonyl compounds measured at YI, YR, GI, GR, and SC sites. Formaldehyde and acetaldehyde were found at higher detection frequencies (96-100\%) at all sites followed by methyl ethyl ketone (73-91\%). The compounds, such as butyraldehyde, $i$-valeraldehyde, and $n$-valeraldehyde, were 

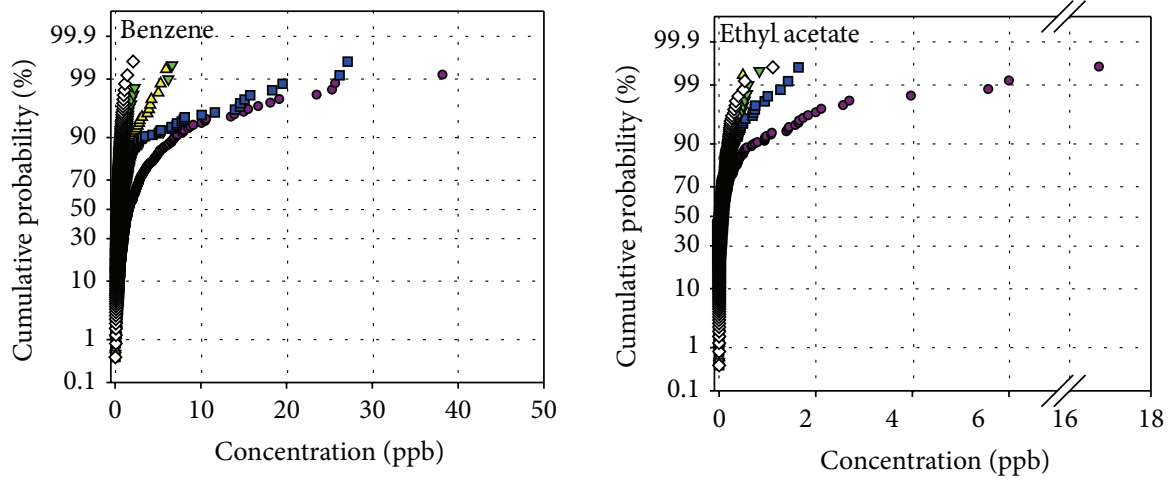

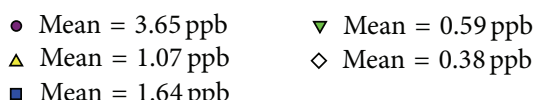

$\begin{array}{ll}\text { - Mean }=0.39 \mathrm{ppb} & \nabla \text { Mean }=0.10 \mathrm{ppb} \\ \Delta \text { Mean }=0.11 \mathrm{ppb} & \diamond \text { Mean }=0.07 \mathrm{ppb} \\ \text { - Mean }=0.12 \mathrm{ppb} & \end{array}$
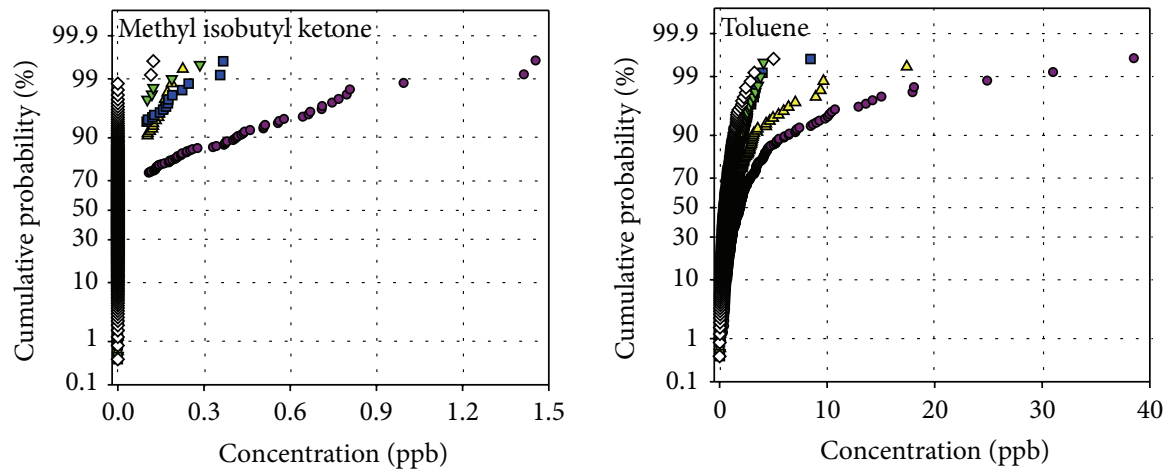

$\begin{array}{ll}\text { - Mean }=0.11 \mathrm{ppb} & \nabla \text { Mean } \leq 0.01 \mathrm{ppb} \\ \triangle \text { Mean }=0.01 \mathrm{ppb} & \diamond \text { Mean } \leq 0.01 \mathrm{ppb} \\ \text { - Mean }=0.01 \mathrm{ppb} & \end{array}$

- Mean $=3.25 \mathrm{ppb}$

$\nabla$ Mean $=0.98 \mathrm{ppb}$

$\triangle$ Mean $=1.61 \mathrm{ppb}$

$\diamond$ Mean $=0.68 \mathrm{ppb}$

- Mean $=0.97 \mathrm{ppb}$
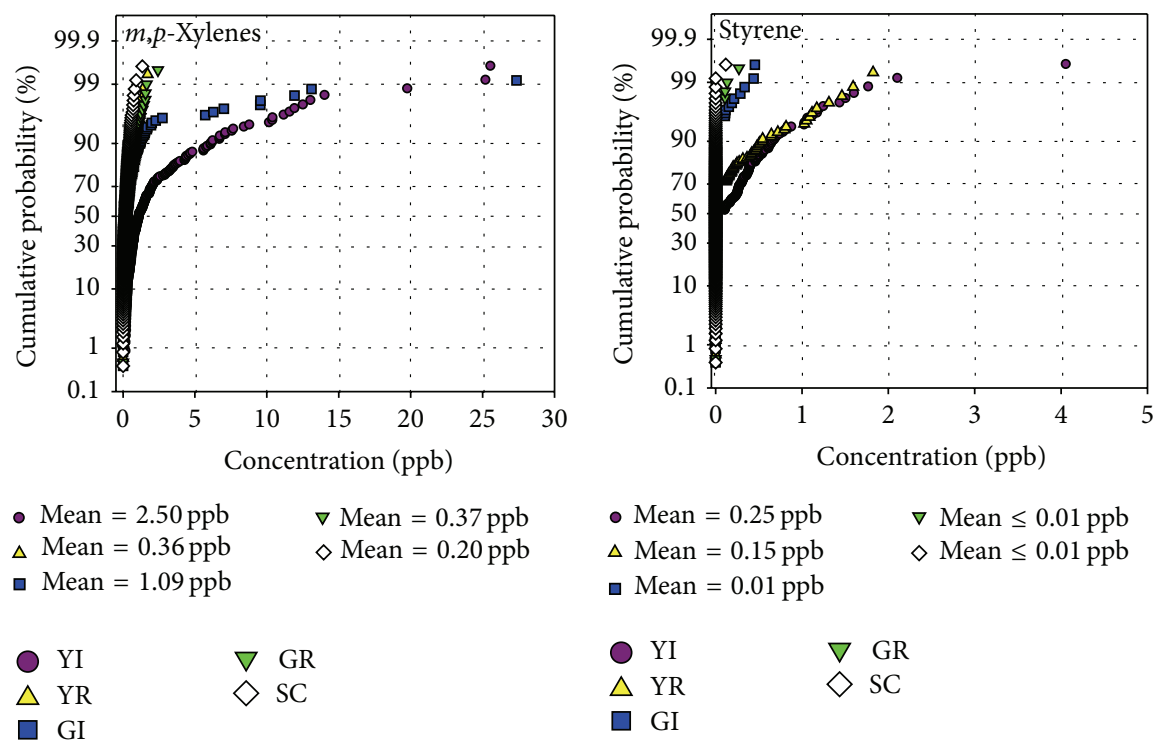
- Mean $=0.25 \mathrm{ppb}$
$\nabla$ Mean $\leq 0.01 \mathrm{ppb}$
$\Delta$ Mean $=0.15 \mathrm{ppb}$
$\diamond$ Mean $\leq 0.01 \mathrm{ppb}$
- Mean $=0.01 \mathrm{ppb}$
YI
$\triangle \mathrm{YR}$
$\nabla$ GR
$\diamond \mathrm{SC}$

FIgURE 3: Cumulative probability of the distributions of the concentrations of VOC.

detected with the lowest frequencies at all sites. Regarding the concentrations of odorous carbonyls, acetaldehyde, methyl ethyl ketone, and propionaldehyde were found to be higher in all sampling sites than the others. On the other hand, the concentration of formaldehyde found was higher than any other carbonyl compound at all sites. Butyraldehyde, $i$ valeraldehyde, and $n$-valeraldehyde were observed at lower concentrations at all sites. 

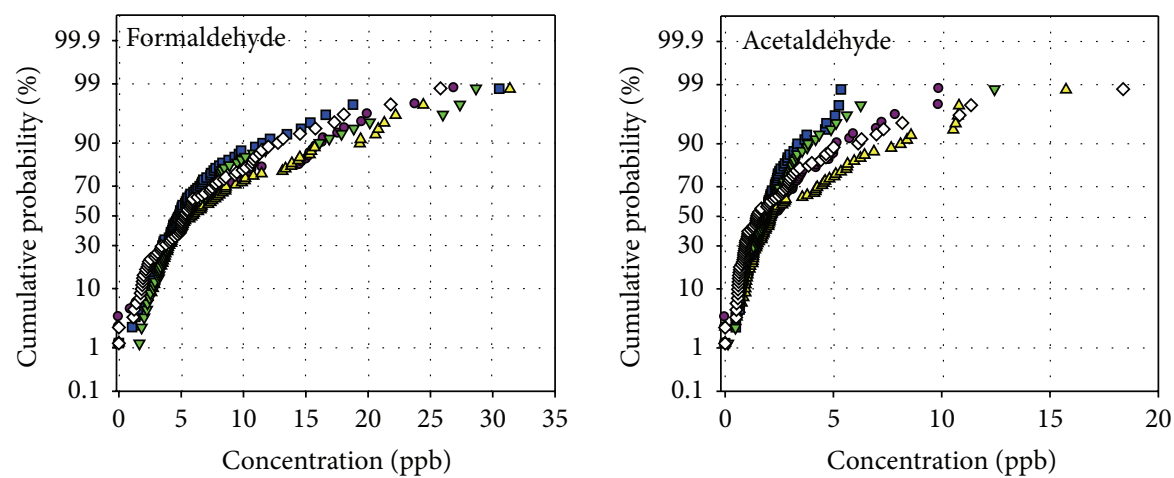

$\begin{array}{ll}\text { - Mean }=7.40 \mathrm{ppb} & \nabla \text { Mean }=7.15 \mathrm{ppb} \\ \Delta \text { Mean }=8.06 \mathrm{ppb} & \diamond \text { Mean }=6.52 \mathrm{ppb} \\ \text { - Mean }=5.99 \mathrm{ppb} & \end{array}$

- Mean $=2.75 \mathrm{ppb} \quad \nabla$ Mean $=2.23 \mathrm{ppb}$

$\triangle$ Mean $=3.43 \mathrm{ppb} \quad \diamond$ Mean $=2.54 \mathrm{ppb}$

- Mean $=1.97 \mathrm{ppb}$
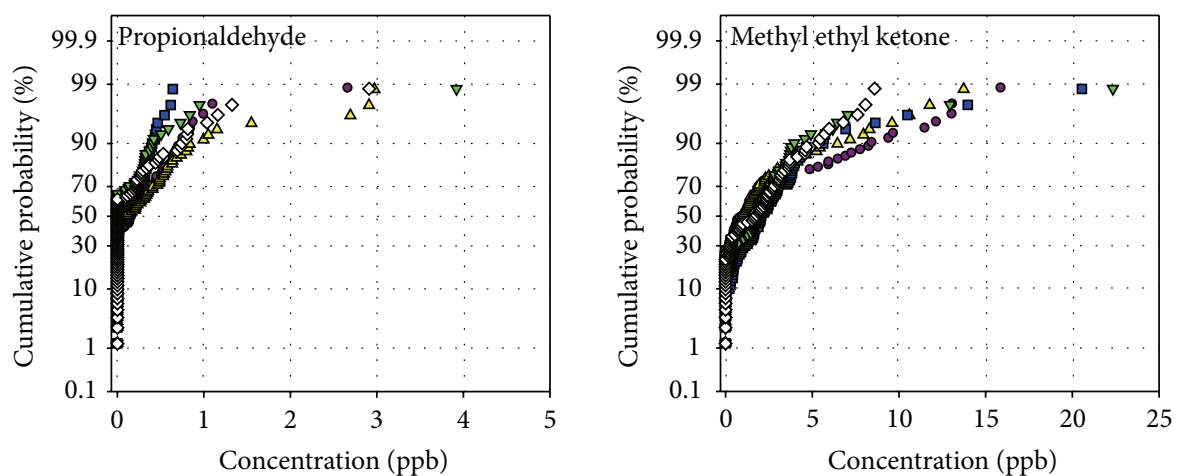

$\begin{array}{rlrl}\text { - Mean } & =0.29 \mathrm{ppb} & & \nabla \text { Mean }=0.17 \mathrm{ppb} \\ \Delta \text { Mean } & =0.35 \mathrm{ppb} & & \diamond \text { Mean }=0.21 \mathrm{ppb} \\ \text { - Mean } & =0.14 \mathrm{ppb} & \end{array}$

- Mean $=2.57 \mathrm{ppb} \quad \nabla$ Mean $=2.29 \mathrm{ppb}$

$\triangle$ Mean $=2.05 \mathrm{ppb} \quad \diamond$ Mean $=2.05 \mathrm{ppb}$

- Mean $=2.73 \mathrm{ppb}$
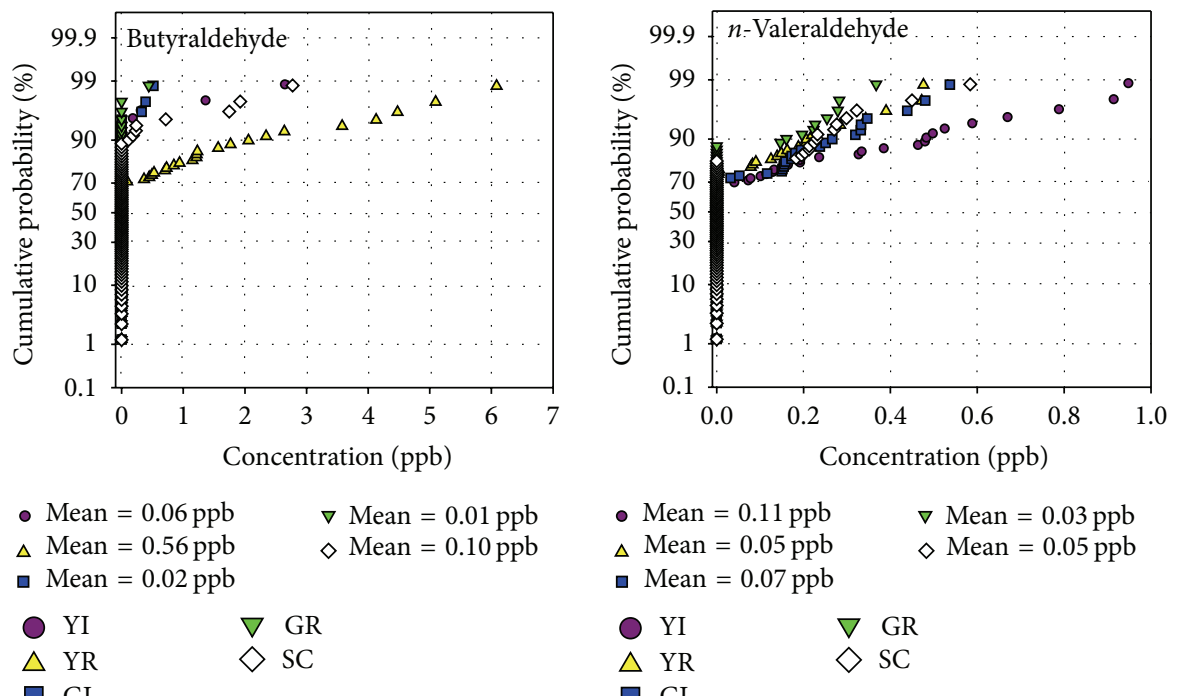

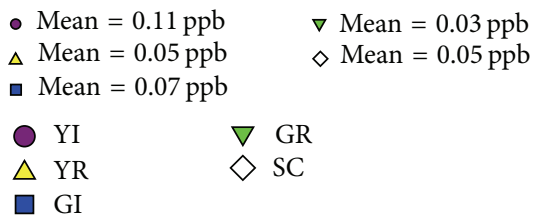

FIGURE 4: Cumulative probability of distributions of the concentrations of carbonyl compounds.

3.2. Spatial Distribution of VOC and Carbonyl Compounds. Figures 3 and 4 present the cumulative probabilities of distributions of the concentrations of the VOC and carbonyl compounds measured at all five sites (YI, YR, GI, GR, and $\mathrm{SC})$. All the measured VOC showed higher levels at the Yeosu
Industrial (YI) site and lower levels at the control site (SC) compared to the other sites. Benzene and $m, p$-xylenes were observed to be higher at the industrial sites (YI and GI) than the residential sites. Toluene and styrene showed higher levels at the Yeosu industrial and residential sites than the other 

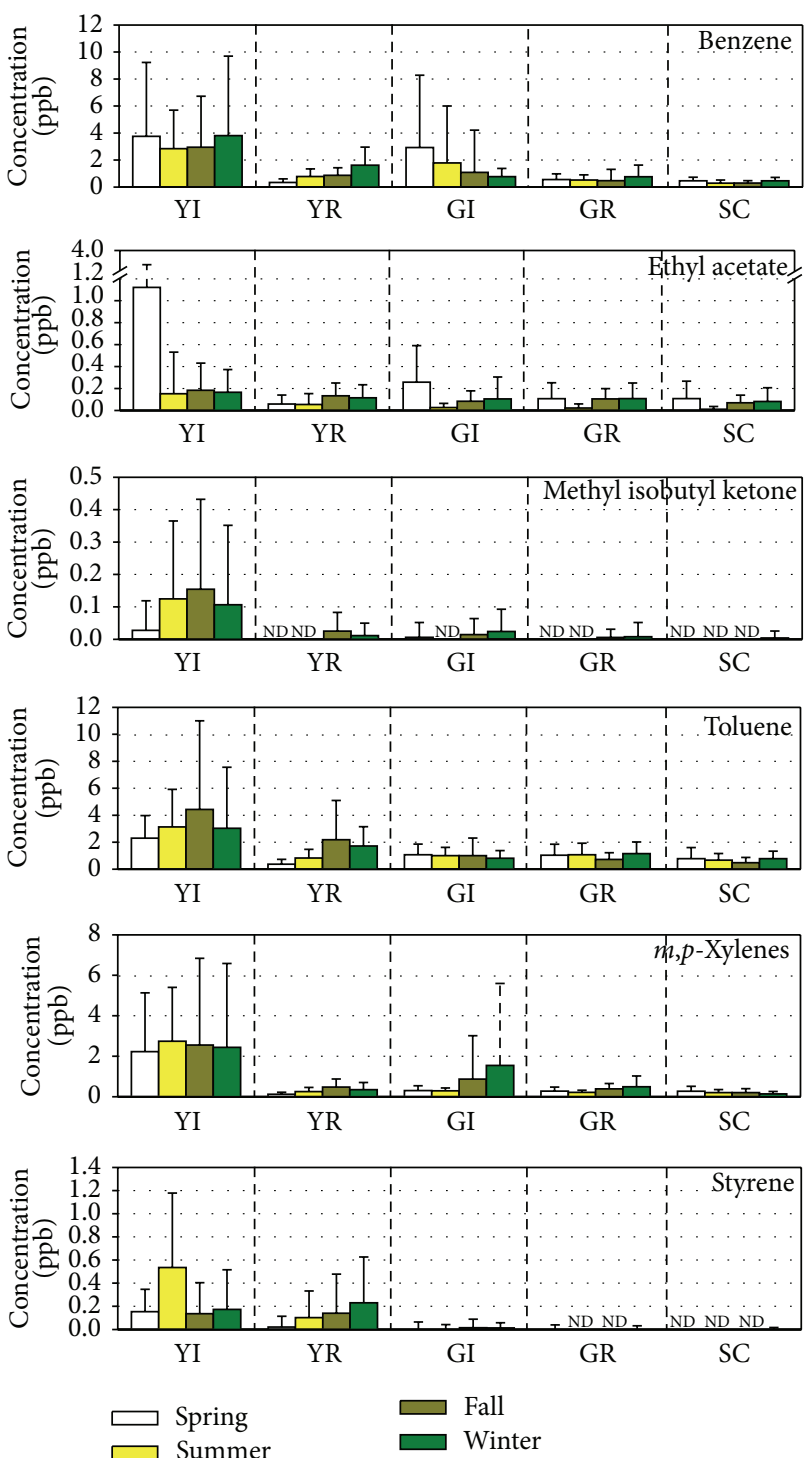

FIGURE 5: Seasonal variations of concentrations of VOC.

sites. The concentration of benzene at YI site was almost 2-9 times higher than the other sites. Regarding carbonyl compounds, a few of them were higher at the residential site (YR) than at the other sites. Carbonyl compounds are not only emitted from primary sources but also formed by photochemical reactions in the atmosphere (secondary sources). This might explain the higher concentrations of few carbonyls at residential sites than the industrial sites. The residential areas were affected from the emissions of industrial and traffic sources.

3.3. Seasonal Variations in Concentrations of VOC and Carbonyl Compounds. To understand the seasonal influence on the concentrations of VOC and carbonyl compounds, their concentrations were measured during four seasons of the year and are shown in Figures 5 and 6, respectively. From this study, the concentrations of VOC and carbonyl compounds were not much influenced by the seasons. Owing to
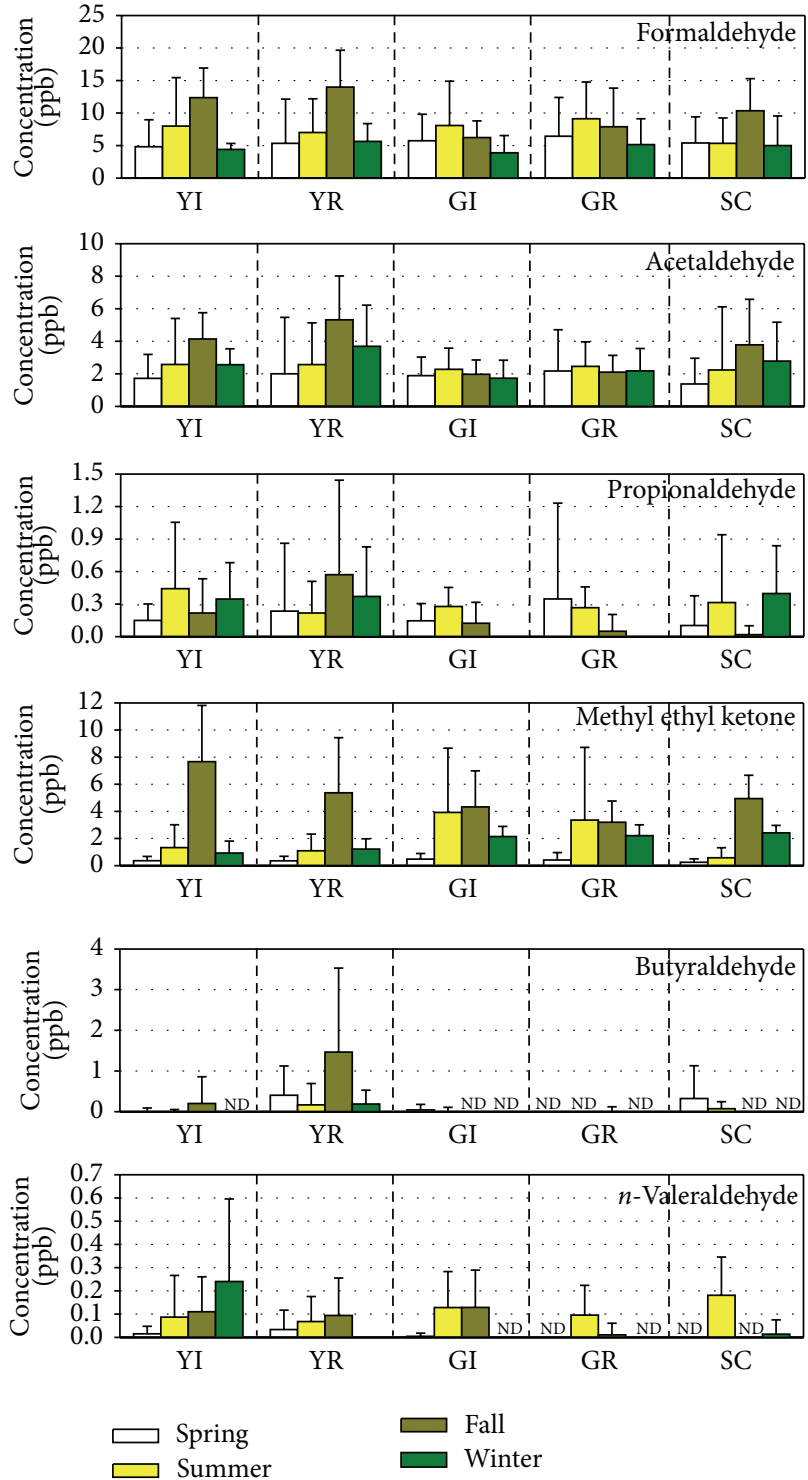

FIGURE 6: Seasonal variations of the concentrations of carbonyl compounds.

multisources and secondary reactions in the atmosphere, the concentrations of these compounds did not show constant variations in different seasons.

3.4. Odor Intensity of VOC and Carbonyl Compounds. Most researchers measured the concentrations of the VOC and carbonyl compounds in ambient air. On the other hand, the concentrations may not indicate their precise impact on the people's health, particularly odorous compounds. A new parameter, odor intensity, was introduced to evaluate the accurate odor impact on people when they perceived these compounds. The odor intensity of a compound can be calculated by dividing the target analyte concentration with the standard (reference) odor intensity value of that compound. The reference values were taken from the Japanese Odor Control Law (http://www.env.go.jp/en/laws/air/odor/opm.html, 

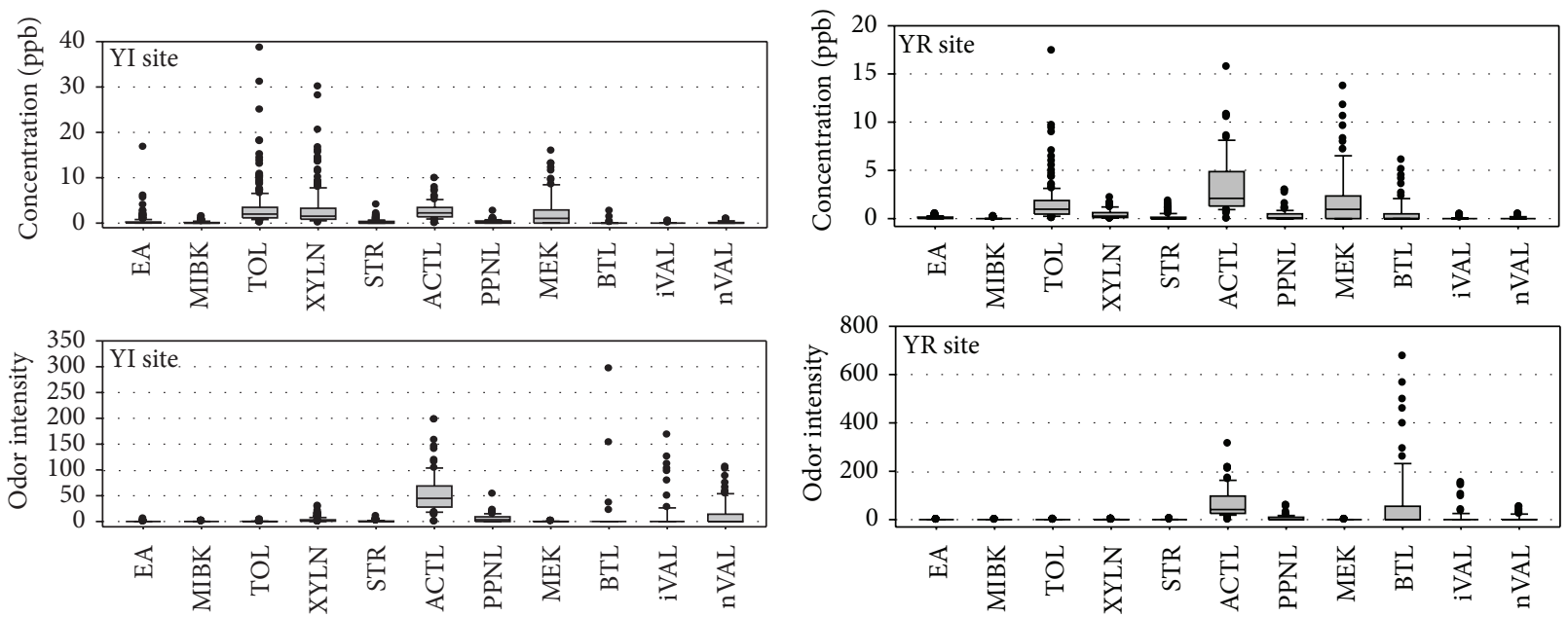

(a)

(b)
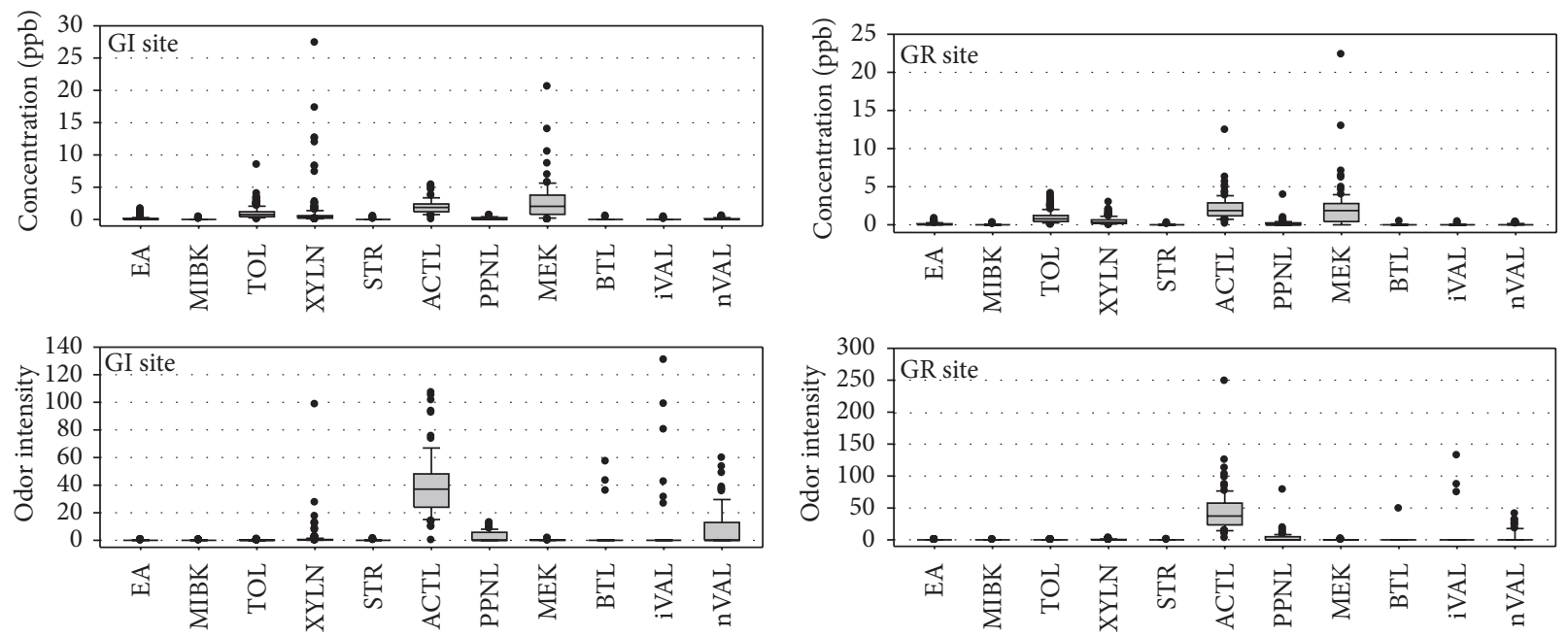

(c)

(d)
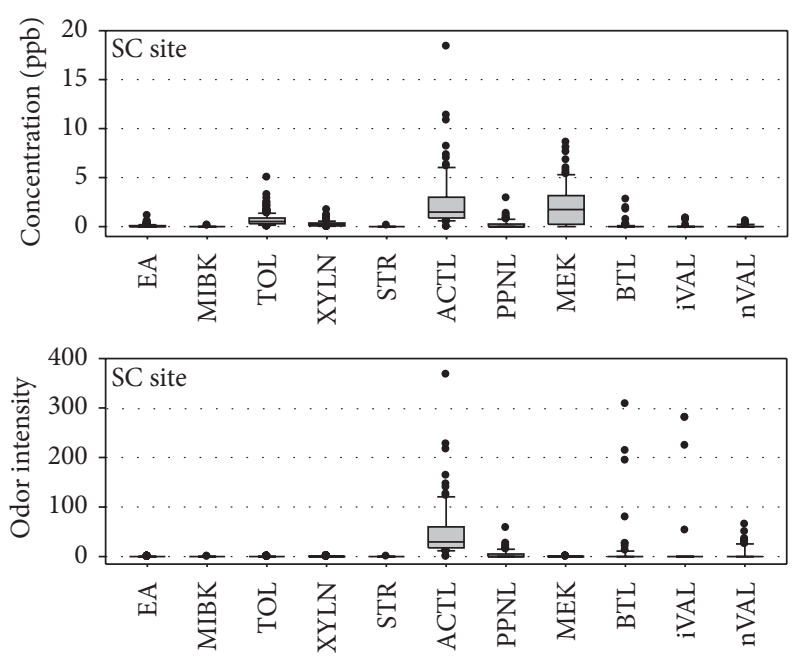

(e)

FIGURE 7: (a) Concentration and odor intensity of the odor compounds at YI site. (b) Concentration and odor intensity of the odor compounds at YR site. (c) Concentration and odor intensity of the odor compounds at GI site. (d) Concentration and odor intensity of the odor compounds at GR site. (e) Concentration and odor intensity of the odor compounds at SC site. 
TAble 7: (a) Pearson correlation coefficients between the different VOC. (b) Pearson correlation coefficients between VOC and other air quality parameters.

(a)

\begin{tabular}{|c|c|c|c|c|c|c|c|}
\hline Sites & Compounds & Benzene & Ethyl acetate & MIBK & Toluene & $m, p$-Xylenes & Styrene \\
\hline \multirow{6}{*}{ YI } & Ethyl acetate & 0.053 & & & & & \\
\hline & MIBK & $0.317^{*}$ & 0.059 & & & & \\
\hline & Toluene & $0.545^{*}$ & 0.070 & $0.581^{*}$ & & & \\
\hline & $m, p$-Xylenes & $0.532^{*}$ & $0.155^{*}$ & $0.753^{*}$ & $0.692^{*}$ & & \\
\hline & Styrene & $0.278^{*}$ & 0.051 & $0.267^{*}$ & $0.408^{*}$ & $0.396^{*}$ & \\
\hline & $o$-Xylene & $0.410^{*}$ & 0.084 & $0.773^{*}$ & $0.644^{*}$ & $0.857^{*}$ & $0.430^{*}$ \\
\hline \multirow{6}{*}{ YR } & Ethyl acetate & $0.262^{*}$ & & & & & \\
\hline & MIBK & 0.114 & $0.402^{*}$ & & & & \\
\hline & Toluene & $0.278^{*}$ & $0.178^{*}$ & $0.284^{*}$ & & & \\
\hline & $m, p$-Xylenes & $0.380^{*}$ & $0.601^{*}$ & $0.475^{*}$ & $0.212^{*}$ & & \\
\hline & Styrene & $0.367^{*}$ & $0.256^{*}$ & $0.329^{*}$ & $0.425^{*}$ & $0.302^{*}$ & \\
\hline & $o$-Xylene & $0.385^{*}$ & $0.644^{*}$ & $0.445^{*}$ & $0.269^{*}$ & $0.949^{*}$ & $0.349^{*}$ \\
\hline \multirow{6}{*}{ GI } & Ethyl acetate & 0.027 & & & & & \\
\hline & MIBK & -0.016 & $0.220^{*}$ & & & & \\
\hline & Toluene & $0.413^{*}$ & $0.187^{*}$ & $0.391^{*}$ & & & \\
\hline & $m, p$-Xylenes & 0.032 & -0.031 & $0.300^{*}$ & $0.638^{*}$ & & \\
\hline & Styrene & -0.006 & -0.011 & $0.327^{*}$ & $0.450^{*}$ & $0.454^{*}$ & \\
\hline & $o$-Xylene & 0.027 & -0.028 & $0.293^{*}$ & $0.646^{*}$ & $0.986^{*}$ & $0.458^{*}$ \\
\hline \multirow{6}{*}{ GR } & Ethyl acetate & $0.201^{*}$ & & & & & \\
\hline & MIBK & $0.143^{*}$ & $0.285^{*}$ & & & & \\
\hline & Toluene & $0.416^{*}$ & $0.490^{*}$ & $0.343^{*}$ & & & \\
\hline & $m, p$-Xylenes & $0.466^{*}$ & $0.449^{*}$ & $0.329^{*}$ & $0.677^{*}$ & & \\
\hline & Styrene & $0.159^{*}$ & 0.011 & -0.019 & $0.219^{*}$ & $0.224^{*}$ & \\
\hline & $o$-Xylene & $0.473^{*}$ & $0.466^{*}$ & $0.288^{*}$ & $0.651^{*}$ & $0.953^{*}$ & $0.192^{*}$ \\
\hline \multirow{6}{*}{$\mathrm{SC}$} & Ethyl acetate & $0.271^{*}$ & & & & & \\
\hline & MIBK & $0.159^{*}$ & $0.193^{*}$ & & & & \\
\hline & Toluene & $0.645^{*}$ & $0.217^{*}$ & $0.230^{*}$ & & & \\
\hline & $m, p$-Xylenes & $0.500^{*}$ & $0.256^{*}$ & $0.131^{*}$ & $0.735^{*}$ & & \\
\hline & Styrene & $0.158^{*}$ & 0.024 & $0.706^{*}$ & $0.241^{*}$ & 0.117 & \\
\hline & $o$-Xylene & $0.511^{*}$ & $0.310^{*}$ & $0.190^{*}$ & $0.718^{*}$ & $0.978^{*}$ & $0.151^{*}$ \\
\hline
\end{tabular}

(b)

\begin{tabular}{|c|c|c|c|c|c|c|c|c|}
\hline Sites & Compounds & $\mathrm{SO}_{2}$ & $\mathrm{PM}_{10}$ & $\mathrm{O}_{3}$ & $\mathrm{NO}_{2}$ & $\mathrm{CO}$ & Temp. $\left({ }^{\circ} \mathrm{C}\right)$ & Wind speed $(\mathrm{m} / \mathrm{s})$ \\
\hline \multirow{7}{*}{ YI } & Benzene & -0.074 & $0.130^{*}$ & $-0.294^{* *}$ & $0.253^{*}$ & $0.156^{*}$ & $-0.144^{*}$ & $-0.214^{*}$ \\
\hline & Ethyl acetate & -0.048 & $0.144^{*}$ & 0.052 & 0.081 & -0.057 & 0.079 & -0.109 \\
\hline & MIBK & 0.101 & $0.162^{*}$ & -0.027 & $0.367^{*}$ & -0.064 & 0.063 & $-0.266^{*}$ \\
\hline & Toluene & 0.053 & $0.254^{*}$ & -0.077 & $0.463^{*}$ & 0.024 & 0.048 & $-0.297^{*}$ \\
\hline & $m, p$-Xylenes & 0.030 & $0.235^{*}$ & -0.121 & $0.377^{*}$ & -0.038 & 0.063 & $-0.297^{*}$ \\
\hline & Styrene & $0.196^{*}$ & $0.188^{*}$ & $-0.239^{* *}$ & $0.199^{*}$ & -0.022 & $0.223^{*}$ & $-0.253^{*}$ \\
\hline & $o$-Xylene & 0.048 & $0.140^{*}$ & -0.127 & $0.302^{*}$ & -0.079 & $0.191^{*}$ & $-0.330^{*}$ \\
\hline \multirow{7}{*}{ YR } & Benzene & $0.187^{*}$ & $0.317^{*}$ & $-0.424^{*}$ & $0.461^{*}$ & $0.592^{*}$ & $-0.370^{*}$ & 0.053 \\
\hline & Ethyl acetate & $0.412^{*}$ & $0.341^{*}$ & $-0.370^{*}$ & $0.462^{*}$ & $0.290^{*}$ & -0.060 & $-0.289^{*}$ \\
\hline & MIBK & $0.333^{*}$ & 0.133 & $-0.207^{*}$ & $0.280^{*}$ & 0.081 & 0.022 & -0.063 \\
\hline & Toluene & 0.013 & 0.141 & $-0.220^{*}$ & $0.217^{*}$ & $0.166^{*}$ & -0.087 & 0.098 \\
\hline & $m, p$-Xylenes & $0.589^{*}$ & $0.322^{*}$ & $-0.473^{*}$ & $0.552^{*}$ & $0.428^{*}$ & 0.003 & $-0.373^{*}$ \\
\hline & Styrene & -0.013 & 0.093 & $-0.287^{*}$ & $0.316^{*}$ & $0.351^{*}$ & -0.112 & -0.069 \\
\hline & $o$-Xylene & $0.516^{*}$ & $0.323^{*}$ & $-0.468^{*}$ & $0.542^{*}$ & $0.373^{*}$ & 0.011 & $-0.362^{*}$ \\
\hline
\end{tabular}


(b) Continued.

\begin{tabular}{|c|c|c|c|c|c|c|c|c|}
\hline Sites & Compounds & $\mathrm{SO}_{2}$ & $\mathrm{PM}_{10}$ & $\mathrm{O}_{3}$ & $\mathrm{NO}_{2}$ & $\mathrm{CO}$ & Temp. $\left({ }^{\circ} \mathrm{C}\right)$ & Wind speed $(\mathrm{m} / \mathrm{s})$ \\
\hline \multirow{7}{*}{ GI } & Benzene & $0.586^{*}$ & $0.367^{*}$ & 0.098 & $0.385^{*}$ & 0.070 & $0.213^{*}$ & -0.069 \\
\hline & Ethyl acetate & $0.186^{*}$ & $0.151^{*}$ & $0.144^{*}$ & $0.195^{*}$ & $0.155^{*}$ & 0.020 & -0.031 \\
\hline & MIBK & 0.106 & $0.176^{*}$ & $-0.156^{*}$ & $0.228^{*}$ & $0.357^{*}$ & -0.122 & -0.031 \\
\hline & Toluene & $0.316^{*}$ & $0.302^{*}$ & -0.047 & $0.375^{*}$ & 0.122 & $0.154^{*}$ & -0.035 \\
\hline & $m, p$-Xylenes & 0.019 & 0.057 & -0.076 & 0.061 & 0.105 & -0.057 & 0.027 \\
\hline & Styrene & 0.063 & 0.123 & -0.078 & $0.154^{*}$ & $0.164^{*}$ & -0.047 & 0.011 \\
\hline & $o$-Xylene & 0.021 & 0.060 & -0.082 & 0.074 & 0.120 & -0.074 & 0.042 \\
\hline \multirow{7}{*}{ GR } & Benzene & $0.504^{*}$ & $0.423^{*}$ & -0.112 & $0.558^{*}$ & $0.448^{*}$ & -0.017 & $-0.185^{*}$ \\
\hline & Ethyl acetate & $0.311^{*}$ & $0.334^{*}$ & -0.105 & $0.384^{*}$ & $0.249^{*}$ & -0.048 & $-0.206^{*}$ \\
\hline & MIBK & $0.265^{*}$ & $0.173^{*}$ & $-0.141^{*}$ & $0.275^{*}$ & $0.241^{*}$ & -0.056 & -0.060 \\
\hline & Toluene & $0.521^{*}$ & $0.360^{*}$ & -0.137 & $0.566^{*}$ & $0.480^{*}$ & 0.016 & $-0.315^{*}$ \\
\hline & $m, p$-Xylenes & $0.430^{*}$ & $0.362^{*}$ & $-0.483^{*}$ & $0.672^{*}$ & $0.591^{*}$ & $-0.199^{*}$ & $-0.355^{*}$ \\
\hline & Styrene & 0.107 & 0.053 & -0.053 & $0.150^{*}$ & 0.131 & -0.056 & -0.090 \\
\hline & $o$-Xylene & $0.384^{*}$ & $0.402^{*}$ & $-0.517^{*}$ & $0.699^{*}$ & $0.584^{*}$ & $-0.192^{*}$ & $-0.369^{*}$ \\
\hline \multirow{7}{*}{ SC } & Benzene & $0.545^{*}$ & $0.512^{*}$ & -0.086 & $0.430^{*}$ & $0.426^{*}$ & -0.108 & -0.080 \\
\hline & Ethyl acetate & $0.218^{*}$ & $0.249^{*}$ & 0.013 & $0.172^{*}$ & $0.175^{*}$ & -0.069 & -0.007 \\
\hline & MIBK & $0.177^{*}$ & 0.063 & -0.034 & 0.068 & 0.106 & -0.075 & -0.011 \\
\hline & Toluene & $0.267^{*}$ & $0.173^{*}$ & $-0.188^{*}$ & $0.274^{*}$ & $0.218^{*}$ & -0.006 & $-0.158^{*}$ \\
\hline & $m, p$-Xylenes & 0.117 & $0.129^{*}$ & $-0.262^{*}$ & $0.325^{*}$ & 0.126 & $0.190^{*}$ & $-0.367^{*}$ \\
\hline & Styrene & 0.082 & 0.061 & -0.020 & 0.046 & 0.118 & -0.056 & -0.010 \\
\hline & $o$-Xylene & $0.127^{*}$ & $0.163^{*}$ & $-0.241^{*}$ & $0.332^{*}$ & 0.119 & $0.228^{*}$ & $-0.361^{*}$ \\
\hline
\end{tabular}

${ }^{*}$ Correlation coefficients are significant at a level of 0.05 .

accessed on July 10,2014) to calculate the odor intensities of the VOC and carbonyls. Figures 7(a), 7(b), 7(c), 7(d), and 7 (e) show the concentrations and odor intensities of odorous compounds measured at the YI, YR, GI, GR, and SC sites, respectively. In an odor intensity point of view, the maximum intensity is more significant than the mean or median value. From these figures, toluene, xylenes, acetaldehyde, and methyl ethyl ketone were found in higher concentrations, and butyraldehyde, $i$-valeraldehyde, and $n$-valeraldehyde were found at lower concentrations at most sites. Regarding the odor intensity; however, the compounds found at lower concentrations (butyraldehyde, $i$-valeraldehyde, and $n$ valeraldehyde) had more odor impact than the compounds with higher concentrations. In the case of acetaldehyde, both the concentrations and odor intensity were high.

3.5. Correlations of the VOC, Carbonyl Compounds, and Air Quality/Meteorological Data. Pearson correlation analysis was performed to examine the factors affecting the concentrations of VOC and carbonyl compounds at the study areas. Tables $7(\mathrm{a})$ and 7 (b) list the correlation coefficients among the VOC and VOC to the other criteria air pollutants and meteorological conditions. In the case of VOC, aromatic VOC, such as, toluene, $m, p$-xylenes, and $o$-xylene, were correlated with each other and indicated a common source. The meteorological conditions, such as temperature and wind speed, showed a low correlation with the VOC indicating that they do not affect the concentrations of VOC at specified sites. Benzene showed a good correlation with $\mathrm{CO}$ at the residential sites (0.592 and 0.448 at YR and GR, resp.), indicating that combustion is a major of benzene. Similarly $\mathrm{NO}_{2}$ and $\mathrm{SO}_{2}$ showed a good correlation with aromatic VOC, suggesting that the fossil fuel combustion and other combustion processes in industries were the major sources of these compounds.

Tables 8(a) and 8(b) present the correlation coefficients among carbonyl compounds and carbonyls with other criteria air pollutants and meteorological conditions. The correlations between the carbonyl compounds and to the combustion related compounds, such $\mathrm{NO}_{2}, \mathrm{SO}_{2}$, and $\mathrm{CO}$, did not show any significant relationships among them, indicating that most of the carbonyl compounds came from fugitive emissions and not from combustion. In the formaldehyde case, it was well correlated with ozone during summer at four sites $(0.648,0.401,0.481$, and 0.709 at YI, YR, GI, and GR, resp.), suggesting that formaldehyde was produced by secondary photochemical reactions, such as ozone [43]. The meteorological conditions were not correlated or negatively correlated with the carbonyls, indicating that the concentrations of carbonyls were unaffected by the seasonal influence. The concentrations of VOC were affected by the wind direction while the same pattern was not observed in case of carbonyls. The concentrations of VOC were affected by the wind direction while the same pattern was not observed in case of carbonyls. The sources of odorous carbonyls seem to be much complex than VOC, and we estimated that they were mostly emitted by local sources and oxidation of primary pollutants (as an example, acetaldehyde from alcohols). In this 
TABle 8: (a) Pearson correlation coefficients between different carbonyl compounds. (b) Pearson correlation coefficients between carbonyl compounds and other air quality parameters.

(a)

\begin{tabular}{|c|c|c|c|c|c|c|c|}
\hline Sites & Compounds & FRML & ACTL & PPNL & MEK & BTL & iVAL \\
\hline \multirow{6}{*}{ YI } & ACTL & $0.838^{*}$ & & & & & \\
\hline & PPNL & $0.356^{*}$ & $0.455^{*}$ & & & & \\
\hline & MEK & $0.507^{*}$ & $0.320^{*}$ & -0.151 & & & \\
\hline & BTL & 0.144 & $0.274^{*}$ & 0.164 & -0.061 & & \\
\hline & iVAL & 0.099 & 0.074 & 0.155 & 0.077 & -0.053 & \\
\hline & VAL & 0.074 & 0.148 & 0.149 & 0.168 & -0.063 & -0.039 \\
\hline \multirow{6}{*}{ YR } & ACTL & $0.821^{*}$ & & & & & \\
\hline & PPNL & $0.638^{*}$ & $0.796^{*}$ & & & & \\
\hline & MEK & $0.363^{*}$ & 0.209 & 0.061 & & & \\
\hline & BTL & $0.287^{*}$ & 0.205 & 0.096 & -0.014 & & \\
\hline & iVAL & $0.328^{*}$ & $0.287^{*}$ & $0.385^{*}$ & $0.385^{*}$ & -0.069 & \\
\hline & VAL & $0.397^{*}$ & $0.301^{*}$ & 0.032 & -0.009 & $0.340^{*}$ & 0.189 \\
\hline \multirow{6}{*}{ GI } & ACTL & $0.428^{*}$ & & & & & \\
\hline & PPNL & $0.266^{*}$ & $0.485^{*}$ & & & & \\
\hline & MEK & 0.064 & 0.022 & -0.063 & & & \\
\hline & BTL & $0.439^{*}$ & $0.293^{*}$ & 0.041 & -0.081 & & \\
\hline & iVAL & 0.011 & 0.050 & 0.001 & $0.356^{*}$ & 0.120 & \\
\hline & VAL & $0.271^{*}$ & 0.141 & $0.303^{*}$ & $0.389^{*}$ & -0.102 & $0.245^{*}$ \\
\hline \multirow{6}{*}{ GR } & ACTL & $0.584^{*}$ & & & & & \\
\hline & PPNL & $0.452^{*}$ & $0.697^{*}$ & & & & \\
\hline & MEK & 0.088 & 0.001 & -0.057 & & & \\
\hline & BTL & -0.028 & 0.004 & -0.040 & 0.020 & & \\
\hline & iVAL & 0.040 & 0.045 & -0.046 & 0.029 & -0.021 & \\
\hline & VAL & 0.123 & 0.095 & 0.059 & 0.057 & -0.039 & 0.179 \\
\hline \multirow{6}{*}{ SC } & ACTL & $0.271^{*}$ & & & & & \\
\hline & PPNL & 0.120 & $0.713^{*}$ & & & & \\
\hline & MEK & $0.425^{*}$ & $0.251^{*}$ & -0.123 & & & \\
\hline & BTL & -0.066 & -0.113 & -0.091 & -0.171 & & \\
\hline & iVAL & -0.054 & $0.426^{*}$ & 0.166 & 0.091 & -0.042 & \\
\hline & VAL & 0.122 & -0.118 & 0.004 & $-0.229^{*}$ & 0.044 & -0.088 \\
\hline
\end{tabular}

${ }^{*}$ Correlation coefficients are significant at a level of 0.05 .

FRML: formaldehyde; ACTL: acetaldehyde; PPNL: propionaldehyde; MEK: methyl ethyl ketone; BTL: butyraldehyde.

iVAL: $i$-valeraldehyde; VAL: $n$-valeraldehyde.

(b)

\begin{tabular}{|c|c|c|c|c|c|c|c|c|}
\hline Sites & Compounds & $\mathrm{SO}_{2}$ & $\mathrm{PM}_{10}$ & $\mathrm{O}_{3}$ & $\mathrm{NO}_{2}$ & $\mathrm{CO}$ & Temp $\left({ }^{\circ} \mathrm{C}\right)$ & Wind speed $(\mathrm{m} / \mathrm{s})$ \\
\hline \multirow{7}{*}{ YI } & FRML & $0.225^{*}$ & $0.298^{*}$ & $0.532^{*}$ & 0.016 & -0.175 & $0.276^{*}$ & -0.160 \\
\hline & ACTL & $0.448^{*}$ & $0.365^{*}$ & $0.279^{*}$ & $0.230^{*}$ & 0.093 & 0.021 & -0.072 \\
\hline & PPNL & $0.345^{*}$ & 0.076 & 0.053 & 0.168 & 0.126 & 0.051 & -0.074 \\
\hline & MEK & -0.089 & 0.139 & $0.237^{*}$ & -0.023 & -0.176 & 0.134 & $-0.267^{*}$ \\
\hline & BTL & $0.575^{*}$ & 0.167 & 0.130 & -0.019 & -0.007 & 0.014 & $0.236^{*}$ \\
\hline & iVAL & -0.016 & 0.014 & $0.275^{*}$ & -0.125 & -0.019 & 0.090 & 0.046 \\
\hline & VAL & -0.012 & 0.099 & -0.049 & 0.072 & 0.110 & $-0.239^{*}$ & 0.049 \\
\hline \multirow{7}{*}{ YR } & FRML & 0.096 & $0.509^{*}$ & 0.115 & $0.498^{*}$ & 0.185 & 0.151 & $-0.246^{*}$ \\
\hline & ACTL & 0.143 & $0.581^{*}$ & -0.112 & $0.714^{*}$ & $0.402^{*}$ & -0.102 & $-0.247^{*}$ \\
\hline & PPNL & 0.084 & $0.337^{*}$ & -0.099 & $0.497^{*}$ & $0.275^{*}$ & -0.079 & $-0.251^{*}$ \\
\hline & MEK & 0.162 & 0.169 & -0.221 & 0.086 & 0.100 & 0.004 & -0.097 \\
\hline & BTL & -0.105 & $0.227^{*}$ & 0.144 & 0.100 & -0.038 & 0.101 & 0.220 \\
\hline & iVAL & 0.033 & 0.062 & -0.157 & 0.090 & 0.084 & 0.055 & -0.173 \\
\hline & VAL & 0.035 & $0.297^{*}$ & 0.107 & 0.209 & 0.049 & $0.251^{*}$ & -0.172 \\
\hline
\end{tabular}


(b) Continued.

\begin{tabular}{|c|c|c|c|c|c|c|c|c|}
\hline Sites & Compounds & $\mathrm{SO}_{2}$ & $\mathrm{PM}_{10}$ & $\mathrm{O}_{3}$ & $\mathrm{NO}_{2}$ & $\mathrm{CO}$ & Temp $\left({ }^{\circ} \mathrm{C}\right)$ & Wind speed $(\mathrm{m} / \mathrm{s})$ \\
\hline \multirow{7}{*}{ GI } & FRML & 0.033 & 0.118 & $0.279^{*}$ & 0.126 & -0.049 & $0.362^{*}$ & -0.127 \\
\hline & ACTL & $0.261^{*}$ & $0.410^{*}$ & 0.058 & $0.525^{*}$ & $0.332^{*}$ & $0.249^{*}$ & $-0.303^{*}$ \\
\hline & PPNL & 0.139 & 0.091 & 0.194 & 0.169 & 0.026 & $0.528^{* *}$ & 0.000 \\
\hline & MEK & $-0.247^{*}$ & -0.062 & -0.195 & -0.195 & -0.073 & 0.132 & -0.030 \\
\hline & BTL & 0.039 & 0.051 & 0.155 & 0.176 & -0.049 & 0.116 & -0.041 \\
\hline & iVAL & -0.063 & 0.119 & -0.028 & 0.038 & -0.004 & 0.066 & -0.087 \\
\hline & VAL & -0.163 & 0.039 & -0.015 & -0.128 & -0.150 & $0.312^{*}$ & 0.021 \\
\hline \multirow{7}{*}{ GR } & FRML & -0.004 & 0.161 & 0.180 & 0.100 & 0.027 & $0.248^{*}$ & -0.197 \\
\hline & ACTL & $0.258^{*}$ & $0.505^{*}$ & 0.044 & $0.478^{*}$ & $0.360^{*}$ & 0.114 & $-0.392^{*}$ \\
\hline & PPNL & 0.004 & 0.072 & 0.141 & 0.069 & 0.007 & 0.200 & -0.174 \\
\hline & MEK & 0.042 & 0.067 & -0.218 & 0.072 & 0.084 & 0.056 & -0.079 \\
\hline & BTL & -0.081 & -0.021 & -0.048 & -0.096 & -0.072 & -0.024 & -0.064 \\
\hline & iVAL & 0.052 & 0.205 & 0.089 & 0.095 & -0.004 & 0.129 & -0.072 \\
\hline & VAL & 0.075 & 0.035 & 0.110 & -0.037 & 0.057 & $0.329^{*}$ & -0.072 \\
\hline \multirow{7}{*}{ SC } & FRML & $0.347^{*}$ & $0.414^{*}$ & 0.015 & $0.460^{*}$ & $0.377^{*}$ & 0.138 & $-0.378^{*}$ \\
\hline & ACTL & $0.295^{*}$ & $0.327^{*}$ & -0.109 & $0.466^{*}$ & $0.348^{*}$ & -0.057 & $-0.405^{*}$ \\
\hline & PPNL & $0.292^{*}$ & $0.223^{*}$ & -0.133 & $0.263^{*}$ & 0.155 & -0.127 & $-0.244^{*}$ \\
\hline & MEK & $0.267^{*}$ & $0.465^{*}$ & -0.063 & $0.488^{*}$ & $0.590^{*}$ & $-0.231^{*}$ & $-0.277^{*}$ \\
\hline & BTL & -0.135 & -0.061 & 0.075 & -0.138 & -0.155 & 0.116 & 0.097 \\
\hline & iVAL & 0.058 & 0.025 & $-0.283^{*}$ & $0.252^{*}$ & $0.300^{*}$ & -0.175 & $-0.237^{*}$ \\
\hline & VAL & -0.162 & -0.120 & 0.189 & -0.196 & -0.198 & $0.396^{*}$ & 0.026 \\
\hline
\end{tabular}

${ }^{*}$ Correlation coefficients are significant at a level of 0.05 .

FRML: formaldehyde; ACTL: acetaldehyde; PPNL: propionaldehyde; MEK: methyl ethyl ketone; BTL: butyraldehyde.

iVAL: $i$-valeraldehyde; VAL: $n$-valeraldehyde.

respect, it is an important task to find out the local sources of carbonyls. At present we do not have much information about the local sources of carbonyls at specified study sites.

3.6. Comparison of the Concentrations of VOC and Carbonyl Compounds of the Present Study with the Others Reported Worldwide. The concentrations of VOC and carbonyl compounds measured in this study were compared with those of other cities in the world and are presented in Tables 9 and 10, respectively. For this purpose, present data was compared with other data measured mainly at industrial and residential sites. The concentration of benzene found in Yeosu Petrochemical Industrial Site is lower than that reported for other petrochemical industrial sites at Mumbai (India) and Kaohsiung (Taiwan) and higher than those reported for Dunkerque (France), Rem-Wu (Taiwan), and Yokohoma (Japan). On the other hand, the benzene concentration found at Gwangyang Steel Industrial Site was lower than that of most steel industrial sites compared except for the Pohang (South Korea) Steel Industrial Site. The toluene to benzene ratio $(\mathrm{T}: \mathrm{B})$ found in the present study was in the range of $0.59-1.79$.

The concentration of formaldehyde (group 1 carcinogen) reported in the present study was lower than that reported at Kolkata (India), Guangzhou (China), and Ansan (South Korea), and higher than at Gumi (South Korea), Rome (Italy), and Mexico City (Mexico). Most researchers worldwide reported very low concentrations of $i$-valeraldehyde and $i$-valeraldehyde and butyraldehyde (except Ansan, South Korea). On the other hand, although they exist at low concentrations, their odor intensity was higher than other higher abundant carbonyl compounds.

3.7. Health Implications of Benzene and Formaldehyde Levels from This Study. The WHO has no standard for benzene, since benzene is known to be nonthreshold pollutant. Instead, the WHO [44] provides a unit risk for benzene, which is $6 \times$ $10^{-6}$. This means that the life time exposure to $1 \mu \mathrm{g} \mathrm{m}^{-3}$ (c.a. $0.31 \mathrm{ppb}$ ) of benzene will cause six cases of leukemia per one million of the population. According to the present results, the mean concentration of benzene was $1.07 \mathrm{ppb}$ (YR) and 0.59 (GR), which may cause six and two leukemia cases among the life-time residents in Yeosu residential area and Gwangyang residential areas, respectively. The unit risk for formaldehyde is $1.3 \times 10^{-5}$. This suggests that the life time exposure to $1 \mu \mathrm{g} \mathrm{m}^{-3}$ (c.a. $0.79 \mathrm{ppb}$ ) of formaldehyde will cause one case of cancer per one million of the population. The mean concentrations of formaldehyde found in the present study were $8.06 \mathrm{ppb}$ (YR), and $7.15 \mathrm{ppb}$ (GR), which may cause forty and seventeen cancer cases among the lifetime residents in Yeosu residential area and Gwangyang residential areas, respectively. This prediction is based solely on the concentrations of the respective compounds measured in this study and the residents of these cities if exposed for a lifetime.

\section{Conclusion}

This paper reported the concentrations of odorous VOC and carbonyl compounds at large industrial areas of South 


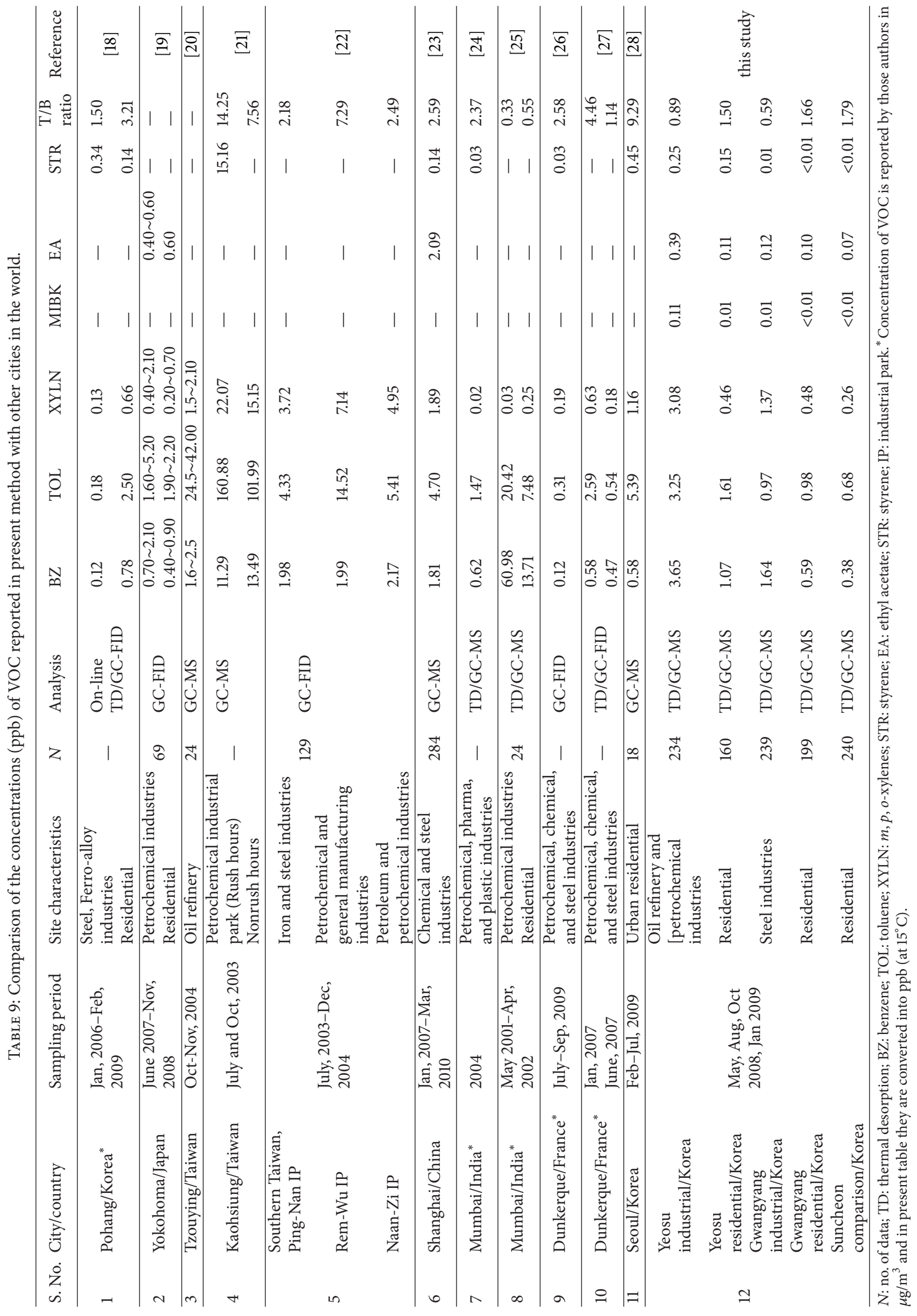




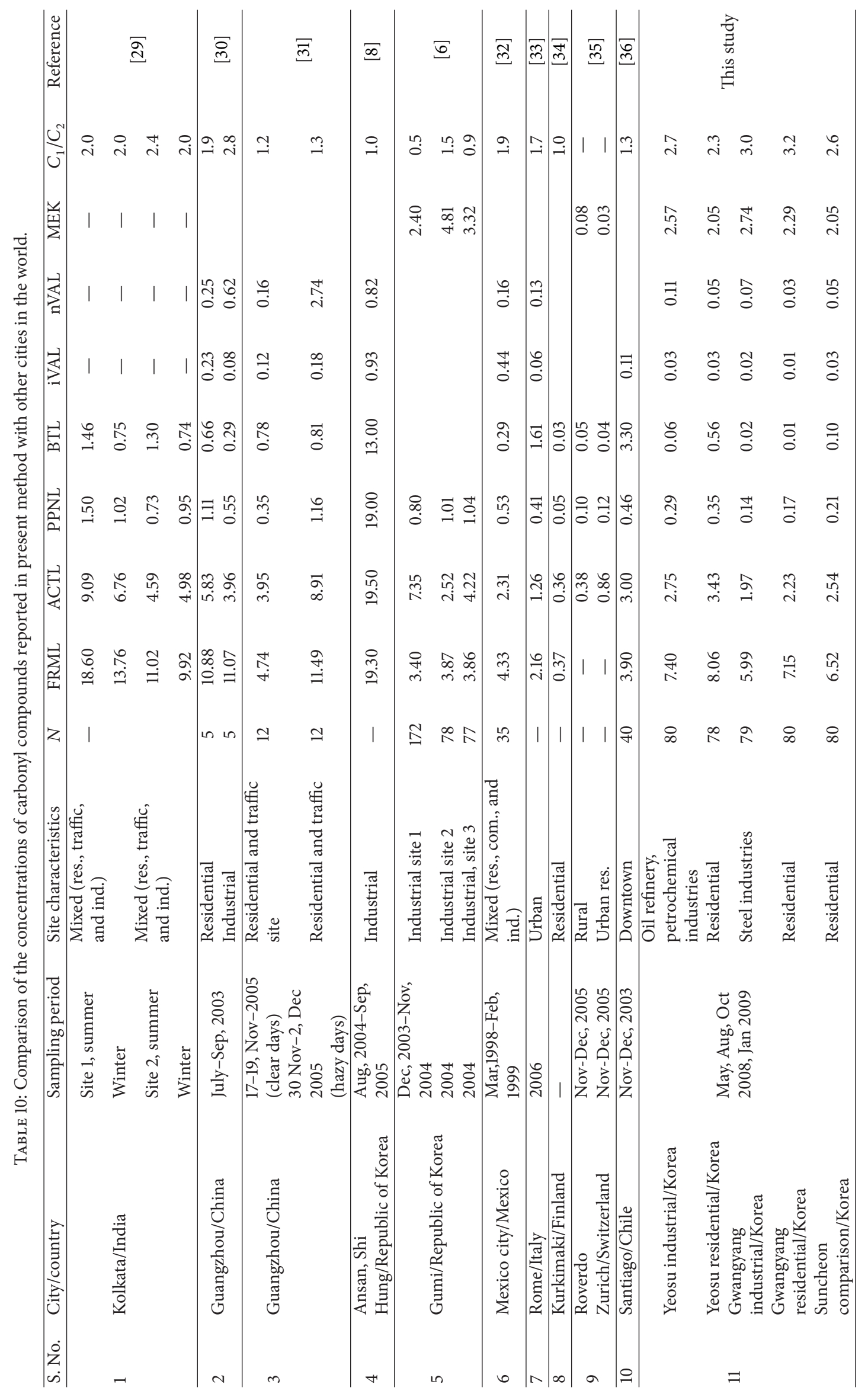


Korea. In this study, the levels of few carbonyls were higher in residential areas near industrial areas. This indicates the influence of industrial sources on the air quality of residential areas in close proximity. Few of the carbonyls were found to be higher in residential areas than in industrial areas; more focus on the determination of the source profiles of these particular compounds is needed. The residential areas provide some sources for these compounds and/or the secondary reactions may also be responsible. In the present study, the odor intensity of the VOC and carbonyls, which gives an accurate impact on the people when they perceived these compounds, was determined. In addition to the odorous compounds, carcinogens, such as, benzene and formaldehyde, were found to be higher at industrial sites than the Korean National Standard Level Concentrations.

\section{Conflict of Interests}

The authors declare that there is no conflict of interests regarding the publication of this paper.

\section{Acknowledgment}

This work was supported by the 2014 Yeungnam University research grant.

\section{References}

[1] A. Feilberg, D. Liu, A.-P. S. Adamsen, M.-J. Hansen, and K.-E. N. Jonassen, "Odorant emissions from intensive pig production measured by online proton-transfer-reaction mass spectrometry," Environmental Science and Technology, vol. 44, no. 15, pp. 5894-5900, 2010.

[2] S. Rappert and R. Müller, "Odor compounds in waste gas emissions from agricultural operations and food industries," Waste Management, vol. 25, no. 9, pp. 887-907, 2005.

[3] R. Both, "Directive on odour in ambient air: an established system of odour measurement and odour regulation in Germany," Water Science and Technology, vol. 44, no. 9, pp. 119-126, 2001.

[4] D. P. Komilis, R. K. Ham, and J. K. Park, "Emission of volatile organic compounds during composting of municipal solid wastes," Water Research, vol. 38, no. 7, pp. 1707-1714, 2004.

[5] M. Cambra-López, A. J. A. Aarnink, Y.Zhao, S. Calvet, and A. G. Torres, "Airborne particulate matter from livestock production systems: a review of an air pollution problem," Environmental Pollution, vol. 158, no. 1, pp. 1-17, 2010.

[6] Y.-K. Seo and S.-O. Baek, "Characterization of carbonyl compounds in the ambient air of an industrial city in Korea," Sensors, vol. 11, no. 1, pp. 949-963, 2011.

[7] K. H. Kim, Y. J. Hong, R. Pal, E. C. Jeon, Y. S. Koo, and Y. Sunwoo, "Investigation of carbonyl compounds in air from various industrial emission sources," Chemosphere, vol. 70, no. 5, pp. 807-820, 2008.

[8] R. Pal, K.-H. Kim, Y.-J. Hong, and E.-C. Jeon, "The pollution status of atmospheric carbonyls in a highly industrialized area," Journal of Hazardous Materials, vol. 153, no. 3, pp. 1122-1135, 2008.

[9] A. Muezzinoglu, "A study of volatile organic sulfur emissions causing urban odors," Chemosphere, vol. 51, no. 4, pp. 245-252, 2003.
[10] E. Davoli, M. L. Gangai, L. Morselli, and D. Tonelli, "Characterisation of odorants emissions from landfills by SPME and GC/MS," Chemosphere, vol. 51, no. 5, pp. 357-368, 2003.

[11] N. E. Rabaud, S. E. Ebeler, L. L. Ashbaugh, and R. G. Flocchini, "Characterization and quantification of odorous and nonodorous volatile organic compounds near a commercial dairy in California," Atmospheric Environment, vol. 37, no. 7, pp. 933940, 2003.

[12] J. Filipy, B. Rumburg, G. Mount, H. Westberg, and B. Lamb, "Identification and quantification of volatile organic compounds from a dairy," Atmospheric Environment, vol. 40, no. 8, pp. 1480-1494, 2006.

[13] Korea Ministry of Environment (KMoE) Present status of designated areas for odor control, KMoE, Seoul, Republic of Korea, 2009, http://www.me.go.kr.

[14] S. Guo and M. Chen, " ${ }^{~} \mathrm{C}$ isotope evidence for photochemical production of atmospheric formaldehyde, acetaldehyde, and acetone pollutants in Guangzhou," Environmental Chemistry Letters, vol. 11, no. 1, pp. 77-82, 2013.

[15] S. Guo, X. He, M. Chen, J. Tan, and Y. Wang, "Photochemical production of atmospheric carbonyls in rural area in southern China," Archives of Environmental Contamination and Toxicology, vol. 66, no. 4, pp. 594-605, 2014.

[16] IARC (International Agency for Research on Cancer), "A review of human carcinogens: chemical agents and related occupations," in IARC Monographs on the Evaluation of Carcinogenic Risks to Humans, vol. 100, IARC, Lyon, France, 2012.

[17] IARC (International Agency for Research on Cancer), $A R C$ Monographs on the Evaluation of Carcinogenic Risks to Humans, Volume 88: Formaldehyde, 2-Butoxyethanol and 1-tert-Butoxypropan-2-ol, IARC, Lyon, France, 2006.

[18] W.-K. Jo, H.-H. Chun, and S.-O. Lee, "Evaluation of atmospheric volatile organic compound characteristics in specific areas in Korea using long-term monitoring data," Environmental Engineering Research, vol. 17, no. 2, pp. 103-110, 2012.

[19] V. Tiwari, Y. Hanai, and S. Masunaga, "Ambient levels of volatile organic compounds in the vicinity of petrochemical industrial area of Yokohama, Japan," Air Quality, Atmosphere and Health, vol. 3, no. 2, pp. 65-75, 2010.

[20] C. Hung-Lung, T. Jiun-Horng, C. Shih-Yu, L. Kuo-Hsiung, and M. Sen-Yi, "VOC concentration profiles in an ozone nonattainment area: a case study in an urban and industrial complex metroplex in southern Taiwan," Atmospheric Environment, vol. 41, no. 9, pp. 1848-1860, 2007.

[21] P. W. G. Liu, Y. C. Yao, J. H. Tsai, Y. C. Hsu, L. P. Chang, and K. H. Chang, "Source impacts by volatile organic compounds in an industrial city of southern Taiwan," Science of the Total Environment, vol. 398, no. 1-3, pp. 154-163, 2008.

[22] L.-T. Hsieh, H.-H. Yang, and H.-W. Chen, "Ambient BTEX and MTBE in the neighborhoods of different industrial parks in Southern Taiwan," Journal of Hazardous Materials, vol. 128, no. 2-3, pp. 106-115, 2006.

[23] C. Cai, F. Geng, X. Tie, Q. Yu, and J. An, "Characteristics and source apportionment of VOCs measured in Shanghai, China," Atmospheric Environment, vol. 44, no. 38, pp. 5005-5014, 2010.

[24] A. Srivastava and D. Som, "Hazardous air pollutants in industrial area of Mumbai-India," Chemosphere, vol. 69, no. 3, pp. 458-468, 2007.

[25] A. Srivastava, A. E. Joseph, and S. Devotta, "Volatile organic compounds in ambient air of Mumbai-India," Atmospheric Environment, vol. 40, no. 5, pp. 892-903, 2006. 
[26] Y. Xiang, H. Delbarre, S. Sauvage et al., "Development of a methodology examining the behaviours of VOCs source apportionment with micro-meteorology analysis in an urban and industrial area," Environmental Pollution, vol. 162, pp. 1528, 2012.

[27] J. Roukos, V. Riffault, N. Locoge, and H. Plaisance, "VOC in an urban and industrial harbor on the French North Sea coast during two contrasted meteorological situations," Environmental Pollution, vol. 157, no. 11, pp. 3001-3009, 2009.

[28] A. Anthwal, C.-G. Park, K. Jung, M.-Y. Kim, and K.-H. Kim, "The temporal and spatial distribution of volatile organic compounds(VOCs) in the urban residential atmosphere of Seoul, Korea," Asian Journal of Atmospheric Environment, vol. 4, no. 1, pp. 42-54, 2010.

[29] C. Dutta, A. Chatterjee, T. K. Jana, A. K. Mukherjee, and S. Sen, "Contribution from the primary and secondary sources to the atmospheric formaldehyde in Kolkata, India," Science of the Total Environment, vol. 408, no. 20, pp. 4744-4748, 2010.

[30] Y. Feng, S. Wen, Y. Chen et al., "Ambient levels of carbonyl compounds and their sources in Guangzhou, China," Atmospheric Environment, vol. 39, no. 10, pp. 1789-1800, 2005.

[31] H. Lü, Q.-Y. Cai, S. Wen et al., "Carbonyl compounds in the ambient air of hazy days and clear days in Guangzhou, China," Atmospheric Research, vol. 94, no. 3, pp. 363-372, 2009.

[32] P. I. Serrano-Trespalacios, L. Ryan, and J. D. Spengler, "Ambient, indoor and personal exposure relationships of volatile organic compounds in Mexico City metropolitan mrea," Journal of Exposure Analysis and Environmental Epidemiology, vol. 14, pp. S118-S132, 2004.

[33] A. Santarsiero and S. Fuselli, "Indoor and outdoor air carbonyl compounds correlation elucidated by principal component analysis," Environmental Research, vol. 106, no. 2, pp. 139-147, 2008.

[34] H. Hellén, H. Hakola, A. Reissell, and T. M. Ruuskanen, "Carbonyl compounds in boreal coniferous forest air in Hyytiälä, Southern Finland," Atmospheric Chemistry and Physics, vol. 4, no. 7, pp. 1771-1780, 2004.

[35] K. Gaeggeler, A. S. H. Prevot, J. Dommen, G. Legreid, S. Reimann, and U. Baltensperger, "Residential wood burning in an Alpine valley as a source for oxygenated volatile organic compounds, hydrocarbons and organic acids," Atmospheric Environment, vol. 42, no. 35, pp. 8278-8287, 2008.

[36] M. A. Rubio, N. Zamorano, E. Lissi, A. Rojas, L. Gutiérrez, and D. Von Baer, "Volatile carbonylic compounds in downtown Santiago, Chile," Chemosphere, vol. 62, no. 6, pp. 1011-1020, 2006.

[37] S.-O. Baek and R. A. Jenkins, "Performance evaluation of simultaneous monitoring of personal exposure to environmental tobacco smoke and volatile organic compounds," Indoor and Built Environment, vol. 10, no. 3-4, pp. 200-208, 2001.

[38] S.-O. Baek and Y.-H. Moon, "Evaluation of adsorbent sampling methods for volatile organic compounds in indoor and outdoor air," Analytical Science and Technology, vol. 17, pp. 496-513, 2004.

[39] Y. K. Seo, L. N. Suvarapu, and S. O. Baek, "Characterization of volatile organic compounds at a heavy-traffic site in Daegu, South Korea," Asian Journal of Chemistry, vol. 25, no. 5, pp. 2912-2922, 2013.

[40] R. Pal and K.-H. Kim, "Experimental choices for the determination of carbonyl compounds in air," Journal of Separation Science, vol. 30, no. 16, pp. 2708-2718, 2007.
[41] USEPA, "Compendium method TO-17: determination of volatile organic compounds in ambient air using active sampling onto sorbent tubes," Tech. Rep. EPA/625/R-96/010b, USEPA, Washington, DC, USA, 1997.

[42] USEPA (Environmental Protection Agency), "Appendix B to Part 136-Definition and procedure for the determination of the method detection limit; 40 CFR," EPA, Washington DC, USA, 1990.

[43] S.-M. Corrêa, G. Arbilla, E.-M. Martins, S.-L. Quitério, C. de Souza Guimarães, and L. V. Gatti, "Five years of formaldehyde and acetaldehyde monitoring in the Rio de Janeiro downtown area-Brazil," Atmospheric Environment, vol. 44, no. 19, pp. 2302-2308, 2010.

[44] WHO, World Health Organization Air Quality Guidelines for Europe, WHO Regional Publication, European Series, World Health Organization, Regional office for Europe, Copenhagen, Denmark, 1999. 

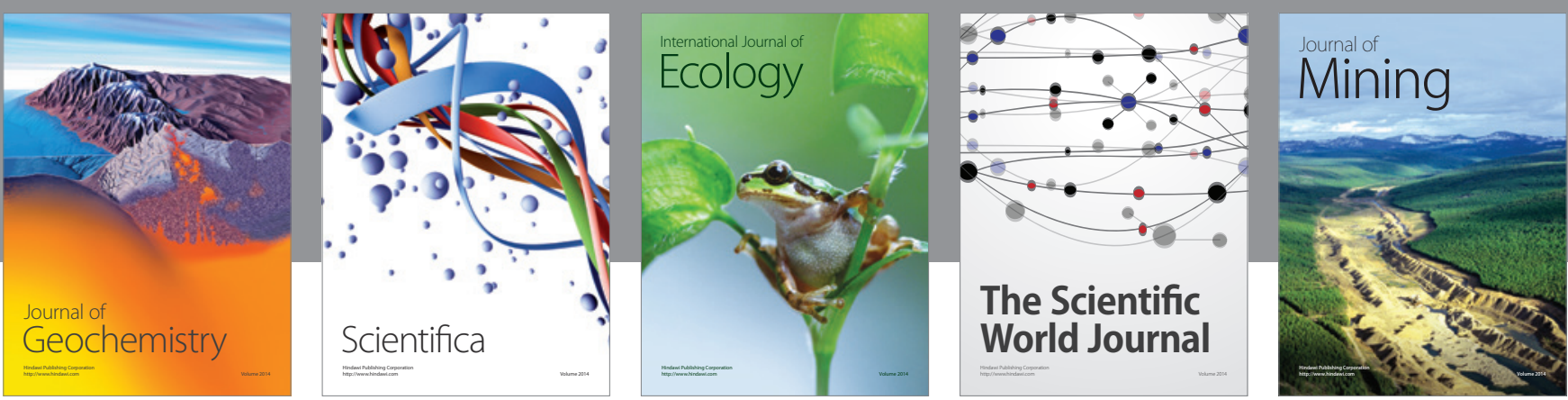

The Scientific World Journal
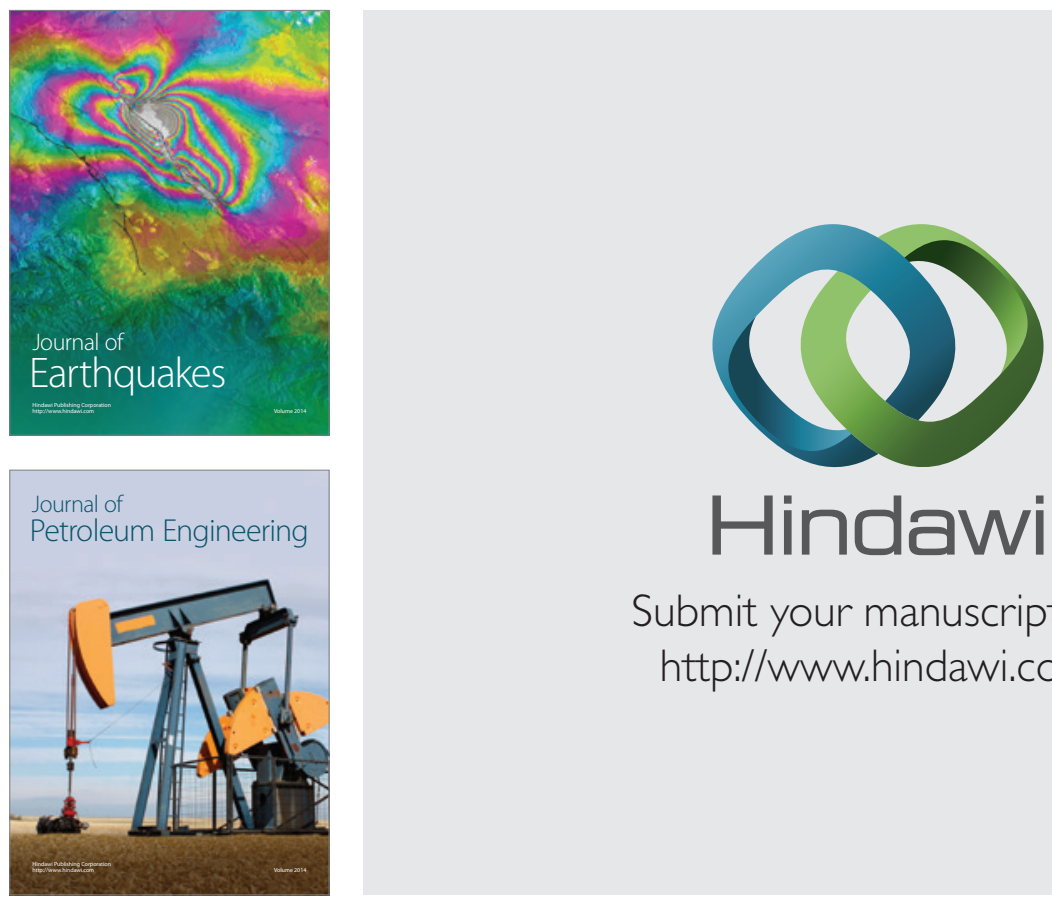

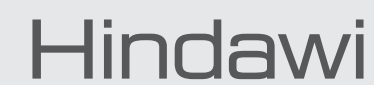

Submit your manuscripts at

http://www.hindawi.com
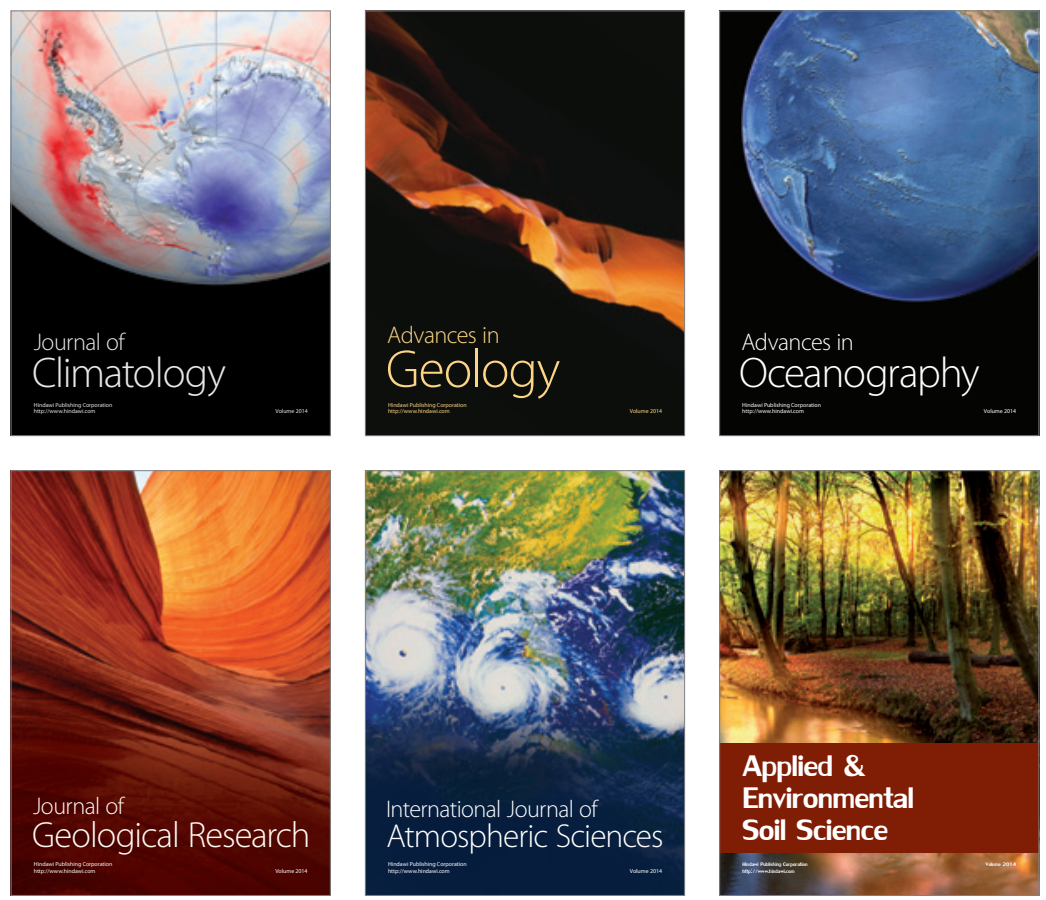
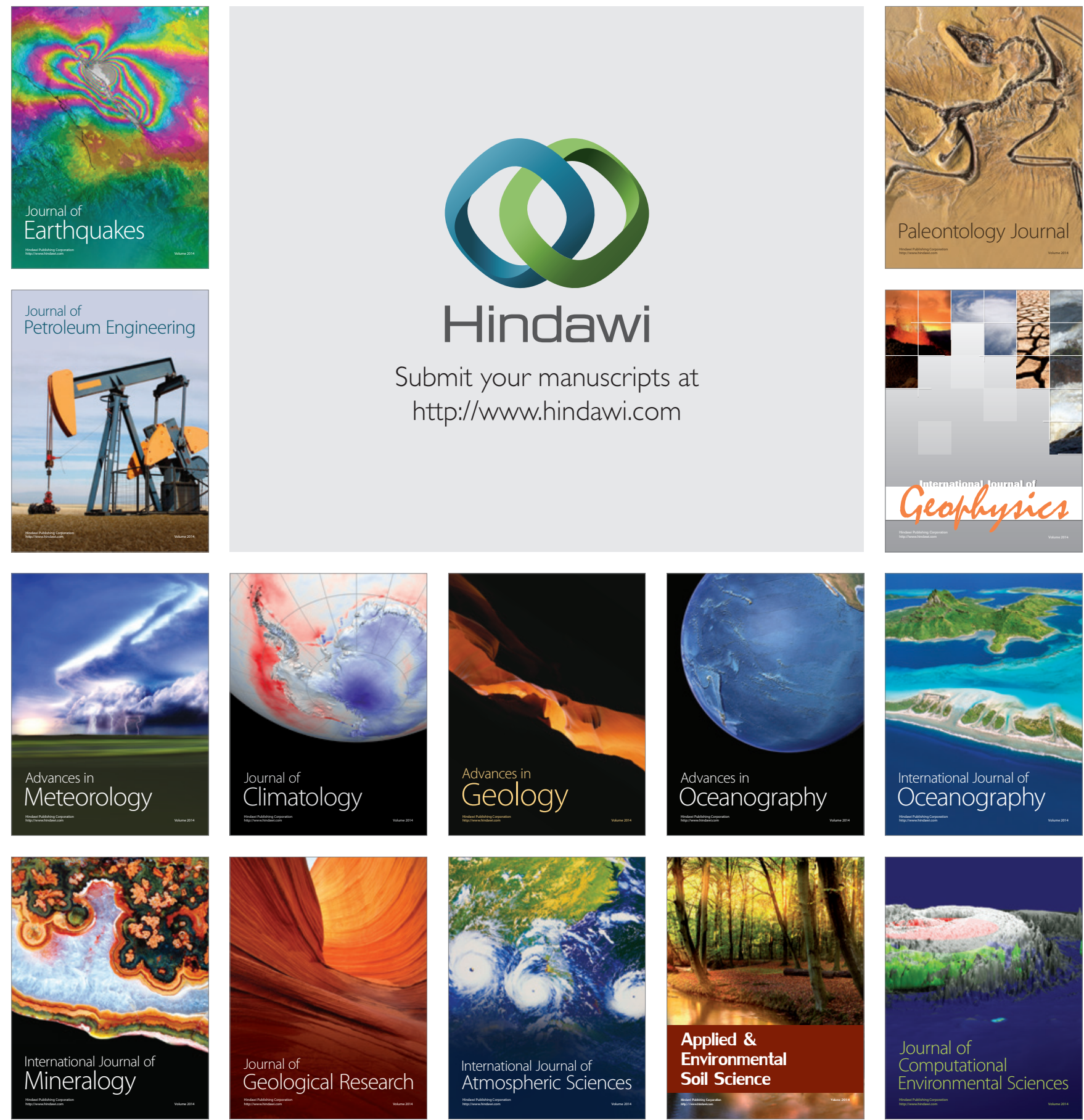